\title{
THE STATUS OF PASSIVE CONSTRUCTIONS IN OLD ENGLISH
}

\author{
HOWARD JONES AND MORGAN MACLEOD
}

FEBRUARY 2017

\begin{abstract}
\end{abstract}
In Old English, passive-type constructions involving a copula and a passive participle could be used to express both events and states. Two different types of copula are found in these constructions: weorðan, meaning 'become' and wesan and beon, meaning 'be'. There has been some dispute as to how the meaning of these copulas relates to the meaning of the construction as a whole, in both its eventive and its stative uses, and whether any of these constructions was grammaticalized in the sense that their meaning was non-compositional. We propose a semantic model that represents these constructions compositionally and test it against a selected corpus of Old English texts in order to address two questions: whether the data provide evidence of noncompositional meaning that would suggest grammaticalization, and whether other factors are also responsible for the choice of copula. Our analysis suggests that the attested Old English passives are fully compatible with a compositional analysis; we also discuss additional semantic factors that may be responsible for the lower frequency of passives with weorðan.

\section{INTRODUCTION}

In Old English there are two types of periphrastic passive construction: those formed with a passive participle and a copula meaning 'become' (weorðan) and those in which the copula involved meant 'be' (wesan or beon). Constructions with a copula and the passive participle of a transitive verb also fall into two broad semantic classes: those denoting events and those denoting states. The mapping between these formal and semantic categories has remained unclear in certain respects. Early studies often identified the 'become' constructions with eventive meaning and the 'be' constructions with stative meaning; however, substantial evidence militates against such a rigid alignment and in particular attests to the frequent use of 'be' 
constructions with eventive meaning (for review see Mitchell 1985: I, 324-33). More recent work has implicitly or explicitly identified eventive meaning with a more advanced stage of grammaticalization (e.g. Denison 1993; Petré \& Cuyckens 2009). Other research has acknowledged the possibility of a compositional analysis for these constructions but has not addressed the semantic and distributional differences between the two types of copula (e.g. Mailhammer \& Smirnova 2013). The present study aims to provide a compositional semantic model in which the range of possible meanings of the two formal classes is clearly related to the semantic content of their components, and to provide empirical data on the form-meaning combinations attested in Old English passives. These will be used to address two questions: first, whether the compositional semantic model proposed can account for the data (i.e. without the need to suppose that grammaticalization has taken place), and second, whether it fully accounts for the observed distribution of the copulas. Our findings are that the compositional semantic model proposed here can account for the full range of data, but that other factors seem also to be involved where the compositional model would allow either copula to be used to convey the same meaning.

The use of both types of copula for passive constructions in Old English reflects a situation found in a number of other early Germanic languages. However, the individual languages have modified this pattern in different ways. For example, Old High German eventually developed an opposition in which the 'be'-passives were restricted to stative constructions, while the 'become'-passives were restricted to events, both transitional and nontransitional (see Jones 2009). In contrast, within English the 'be'-constructions came to predominate; the copula weorðan was eventually lost and its role in the passive was not filled by any of the verbs that supplanted it in more general use. A more detailed understanding of passive constructions in Old English may also shed light on their subsequent development.

\subsection{WESAN AND BEON}

Old English possessed two words meaning 'be', wesan and beon. Although they would eventually be integrated into a single, suppletive paradigm ${ }^{1}$, during the Old English period both

\footnotetext{
${ }^{1}$ The paradigm of wesan was itself already suppletive (see e.g. Ringe \& Taylor 2014).
} 
verbs retained full, discrete paradigms except in the preterite tense, where only wesan is found. The verb beon can be traced to a Proto-Indo-European root meaning 'become', but by the attested Old English period it had come to mean 'be' and was distinguished from wesan largely in having semantic traits that some authors have characterized as 'perfective' in contrast to the 'imperfective' wesan (e.g. Ringe \& Taylor 2014: 373). In research on the passive some authors have treated wesan and beon as already having the status of a single entity, while acknowledging the existence of semantic differences between forms from the two paradigms (e.g. Mitchell 1985; Denison 1993); others have drawn a stronger distinction between the two and discussed the effect that their semantic differences have had on the interpretation of passive constructions formed with them (e.g. Kilpiö 1989; Petré 2014). From a methodological perspective both approaches have certain advantages. In the present work we adopt a two-stage approach to the analysis. We begin by treating the two verbs as a single unit, 'wesan/beon'; at the period in question both these forms shared the meaning 'be', and so they are both dissimilar to a verb such as weorðan 'become' in their lack of any semantically inherent notion of transitionality. Subsequently, however, we explore the semantic and distributional differences (where these occur) between wesan and beon and consider their implications for the passive.

\subsection{THE TERMS ‘PASSIVE’ AND ‘PASSIVE PARTICIPLE’}

We make a distinction, not always explicit in previous treatments, between the function and form of the OE passive. Functionally, the passive typically makes the patient the grammatical subject of a predicate, in contrast to the active, which makes the agent the grammatical subject. Formally, the passive is given by a combination of one of two copular verbs, weorðan or wesan/beon, and the passive participle of a verb. By calling this combination a 'passive' or a 'passive construction' we do not imply anything about whether that combination is grammaticalized or not (see section 2.2 below).

The most appropriate nomenclature for the participle found in OE passive constructions has been the subject of dispute (see Mitchell 1985, I, 12). These forms are often described as 'past participles'; however, they can be used to denote ongoing states contemporaneous with the action of the main verb (see (9) below). They have also been described as 'passive participles'; however, they can also occur with active intransitive meaning, as in the case of forms such as 
druncen and in perfect constructions. Mitchell's own solution was to adopt the semantically neutral term 'second participle'. ${ }^{2}$ In the present work we have chosen to use the more familiar, informative term 'passive participle' to make it clear that the active intransitive use of such participles is excluded.

The combination of these participles with wesan/beon can express perfect meaning as well as passive meaning. Many of these perfect constructions are easily identifiable because the verb involved is intransitive (e.g. feallan 'fall'). However, there are a certain number of verbs, such as wanian 'wane, diminish', which can be either transitive or intransitive, and for which the construction with wesan/beon and the participle can be interpreted either as the passive of a transitive verb or the perfect of an intransitive verb. It has been questioned whether these perfect constructions were actually grammaticalized to the same extent as perfects with habban 'have' (e.g. Mitchell 1985, I, 303-4; McFadden \& Alexiadou 2010). Our position is that, where there is ambiguity, the perfect reading and the passive reading are not two separate, semantically distinct constructions that happen to be formally identical, but rather two different interpretations of a single construction; the temporal anteriority seen in the perfect reading would thus simply be a contextual interpretation of the resultative meaning expressed by a transitional participle (for the semantic model involved see section 3$){ }^{3}$ Accordingly, where the context makes it clear that such constructions are meant as intransitive, they have been excluded from the data, but where a transitive reading is tenable they have been included.

\section{PREVIOUS TREATMENTS OF THE OE PASSIVE}

\subsection{THE FUNCTIONAL DISTRIBUTION OF THE DIFFERENT COPULAS}

It is widely recognized that weorðan and wesan/beon are sometimes used in near-identical contexts in OE, such as in the following pairs:

\footnotetext{
${ }^{2}$ This is in line with the use of the modern German term 'Partizip II' both for the passive participle (typically of transitive verbs), as in die Stadt war/wurde zerstört and for the past participle of active intransitive verbs, e.g. sie ist gekommen.

${ }^{3}$ Such a stance is equally compatible with an analysis in which the participle involved is seen as unspecified for voice and one in which the intransitive verbs involved are categorized as 'unaccusative' verbs with non-agentive subjects and therefore seen as inherently passive-like (see Perlmutter 1978).
} 
(1)

$\begin{array}{cllll}\text { a. On ðæm } & \text { gefeohte wæs } & \text { Cartainiensa } & \text { VII M } & \text { ofslagen, } \\ \text { on the } & \text { fight was } & \text { Carthaginians' } & \text { seven thousand slain, } \\ \& & & \text { VX M } & \text { gefangen } & \\ \text { and } & \text { fifteen thousand } & \text { taken }\end{array}$

'In the battle seven thousand Carthaginians were slain, and fifteen thousand captured.' (Or IV, 6.4.92)

b. Pær wearð Romana XXX M ofslagen, there became Romans' thirty thousand slain, \& Regulus gefangen and Regulus taken 'There thirty thousand Romans were slain, and Regulus captured.' (Or IV, 6.94.17)

$\begin{array}{llllll}\text { a. Pær wæron } & \text { gehælede purh } & \text { ða halgan femnan fela adlige menn } \\ \text { there were } & \text { healed through the holy maiden manyill men }\end{array}$
'There many ailing men were healed by the holy maiden.' (AELS 20.113)

b. Pær wurdon gehælede æt ðære halgan byrgene eahta untrume menn there became healed at the holy tomb eight unsound men 'There at the holy tomb eight men in poor health were healed.' (AELS 21.132)

These pairs, cited by Mitchell (1985, I, 332) and Denison (1993: 418), respectively, appear to show that the two copular verbs are interchangeable when used to denote events. ${ }^{4}$ Mitchell goes even further and argues (ibid. 331-2) that the two copulas can also both be used to form passive constructions denoting states. In support, he cites constructions with weorðan which, he argues, have stative meaning (as constructions with wesan/beon uncontroversially do). Mitchell's strongest examples of 'stative' weorðan passives are as follows:

\footnotetext{
${ }^{4}$ See also Petré (2010: 457-8) and Mailhammer \& Smirnova (2013: 47).
} 
(2)

$\begin{array}{ll}\text { pat } & \text { cwearternwearð afylled mid fulum adelan } \\ \text { the prison became filled with foul addle } \\ \text { and } & \text { butan } \quad \text { celcum leohte atelice stincende } \\ \text { and } & \text { but each light horribly stinking }\end{array}$

'The prison was filled with foul mud, stinking horribly without any light'

(ELS 35.244)

(3)

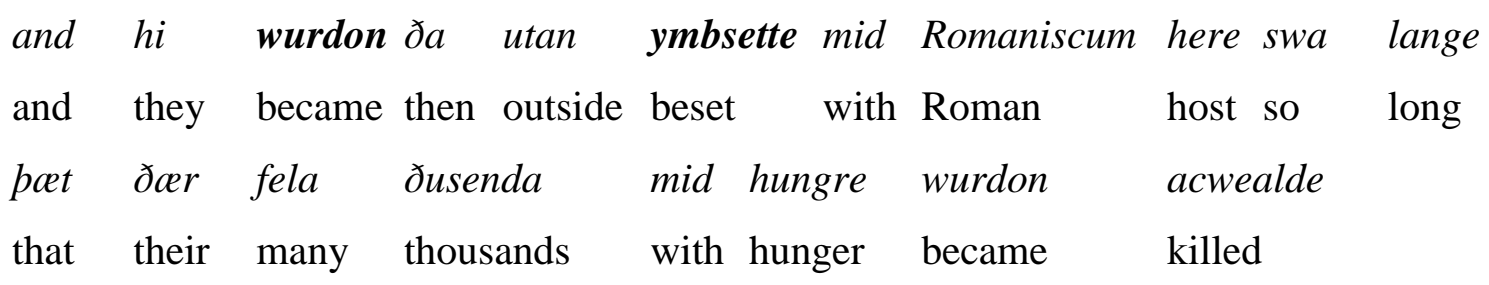

'And they were then besieged outside by the Roman army so long that many thousands of them were starved to death.'

(ECHom I, 402.3)

However, it is possible to read both of these constructions as eventive: in the first the filling of the prison with foul mud is as easily seen as an event as a state; in the second, 'wurdon...ymbsette' can refer to the event of 'becoming besieged' and 'swa lange' to the following period; see the discussion by Denison (ibid.). ${ }^{5}$ In his analysis of two translations from Latin, Bede and CP, Kilpiö (1989: 67, 85) shows that, in both tenses, weorðan + passive participle is used only for 'actional' passives and not at all for stative passives. The functional distribution between copulas appears therefore to be that either copula may be used to form eventive passives, but only wesan/beon is used to form stative passives; the challenge is to account for this distribution. For a summary of the literature, see Petré (2014), chapter 2.

\footnotetext{
${ }^{5}$ Similar issues of interpretation exist with non-passive constructions as well, as is shown by an example such as $\mathrm{Or}$ I 5.23.19 (mid Egyptum wearð syfan gear se ungemetlica eorðwela, \& hi after ðam waron on pan maestan hungre oðre syfan gear.). This example is interpreted by Mitchell (1985, I, 331) as an instance of stative weorðan, but it can also be interpreted in an eventive sense ("Among the Egyptians there occurred immense prosperity for seven years, and after that they were in the greatest hunger for another seven years.'). As the translation suggests, in such contexts the eventive/stative distinction can be partly neutralised.
} 
In other early Germanic languages the use of both 'be' and 'become' in passive constructions which denote events has been well documented. For the Gothic Bible (the main extant Gothic work), Schröder (1957) argues that only waírpan is properly used to denote events and that instances of wisan translating Greek eventive passives must represent either an improvement on the Greek (e.g. 1957: 93) or poor translation practice (1957: 14, 61). Bammesberger (1979: 97) and Jones (2009: 219-26), following Behaghel (1924: 207), acknowledge that waírpan and wisan are sometimes used to translate identical or near-identical eventive Greek passives, and that in such cases the two copulas appear to be interchangeable. For Old Norse, Faarlund (2004: 211-15) and Barnes (2008: 251-2) point out that, while verða (the cognate of weorðan) is used only for 'dynamic' passives, vera (the cognate of wesan) can be either 'dynamic or static'. For OHG the text which has received the most attention in this regard is the OHG Tatian, a (sometimes very close) translation from Latin. Here the pattern is similar to that in Gothic and Old Norse, in that stative Latin passives are translated only with wesan, but eventive Latin passives are translated by both werdan and wesan; as in Gothic, sometimes identical eventive Latin passives are translated by werdan and wesan in different parts of the work. Schröder (1955) adopts a similar approach to the OHG evidence to that which he applies to Gothic, attributing the use of wesan for eventive passives in the OHG Tatian to uncertainty on behalf of the translators (1955: 59). More recently, Eroms (1990), Schrodt (2004), and Jones (2009) (in line with work by Lussky (1924) and Zieglschmid (1929)) acknowledge that passives with wesan can be genuinely eventive, and they attempt to account for the distribution between werdan and wesan in passive constructions in terms of Aktionsart and/or aspect (for definitions of these terms, see sections 5.2-5.3). ${ }^{6}$

Recent work relating to the OE passive has addressed two broad topics. The first is the loss of weorðan from the lexicon (in passive constructions and elsewhere) between OE and ME; for example, Petré (2010) argues that there was a move between OE and ME from 'bounded' to 'unbounded' (usually progressive) sentences, and that weorðan was particularly associated with bounded sentences. The second recent topic is the question of the status of weorðan and wesan/beon + passive participle constructions; thus Mailhammer and Smirnova (2013) explore whether such constructions in OE (and OHG) are compositional (i.e. whether the meaning of the

\footnotetext{
${ }^{6}$ Some treatments of the OHG passive do not engage closely with the OHG Tatian and therefore do not explore the use of wesan for eventive passives in great detail; see Rupp (1956), Oubouzar (1974), and Valentin (1987). For a wider discussion of the role of Aktionsart and aspect in the development of the German verb, see Leiss (1992).
} 
whole construction can be derived from the meaning of its component parts) or grammaticalized (i.e. non-compositional). As a basis for future research, their paper sets out an aspect-based compositional model on which to test the OE evidence. The concept of grammaticalization plays a role in research on both these topics; as a preliminary to further discussion, we clarify in the next section what grammaticalization would involve in the context of passive constructions.

\subsection{GRAMMATICALIZATION AND CONSTRUCTIONALIZATION}

The term 'grammaticalization' relates to the way in which words lose lexical meaning and gain grammatical meaning. The term has been used for a variety of different processes (not necessarily operating together), of which the following four are widely accepted (see Heine (2003): (i) semantic bleaching, i.e. the loss of lexical meaning; (ii) extension, i.e. the use of the word in new contexts; (iii) decategorialization, i.e. the loss of morphosyntactic properties, including a loss of status as an autonomous word; and (iv) phonological erosion. ${ }^{7}$ More recent work on grammaticalization has stressed the importance, often implicit in earlier work, of analysing entire constructions rather than just single words, and argues that some processes of grammaticalization can be understood only by reference to co-text and context (see Bergs and Diewald 2008). In the present work, the term 'grammaticalization' is reserved for processes involving semantic bleaching whereby the meaning of the construction is not deducible compositionally from the meaning of the two parts. Such semantic bleaching is not a necessary element of all forms of grammaticalization, and may be absent from processes such as affixation (e.g. Hopper \& Traugott 2003, 7-10); however, it will be seen below that many of the other criteria proposed for evaluating the grammaticalization of passive constructions are problematic. Grammaticalization is one of the processes for which we will be testing in our empirical analysis. The development of the werden-passive in German will illustrate the process. The copula werden, which has had the meaning 'become' throughout the history of the language, came to be used from late $\mathrm{OHG}$ onwards in passive constructions even where no sense of transition was

\footnotetext{
${ }^{7}$ The precise status of grammaticalization is disputed. A number of linguists, while recognizing that it is a useful description for tendencies in linguistic change, believe that grammaticalization is an epiphenomenon of more basic processes, notably semantic change and reanalysis (see Campbell (2001)).
} 
present, (while the transitional meaning of werden remained outside such constructions). ${ }^{8}$ To this extent werden was semantically bleached within passive constructions, and the combination of werden + passive participle was not compositional.

For processes of linguistic specialization that do not meet our criterion for grammaticalization, non-compositionality, we use the term 'constructionalization'. In passive constructions it is possible that, even if either copula ('to be' or 'to become') could be combined with a passive participle to give the same meaning compositionally (i.e. without grammaticalization), language users might choose to use only one copula rather than the other to convey that meaning. This would be an example of constructionalization. Again we can draw on the history of German to illustrate this process. The copula sein, which has meant 'to be' throughout the history of German, was once used to produce passive constructions with a stative sense as well as those with an eventive sense. However, since late $\mathrm{OHG}$ the use of sein in passive has been reserved for stative passives. In this case the development does not appear to have involved semantic bleaching; instead, the expression of stative passives in German became more systematic and as a result a more rigid association developed between passives with sein (which only have a stative sense in modern German) and those with werden (which only have an eventive sense); see Jones (2009) for details. ${ }^{9}$ In using the term 'constructionalization' we are not analysing this type of change within the framework of Construction Grammar. Rather, in this process we see form-meaning pairs whose systematic use is not derived solely from their component elements (for a review of approaches to such phenomena see Traugott \& Trousdale 2013). In the case of German sein + past participle constructions, the nature of the state described is denoted compositionally by the semantic components of the copula and the participle, but because learners encounter these constructions exclusively in stative contexts, they do not extend them to eventive contexts that might nevertheless be compatible with the meaning of the components. Constructionalization involves a lesser degree of linguistic change than grammaticalization, and is a more parsimonious default hypothesis in the absence of conclusive evidence to distinguish the two types of phenomenon.

\footnotetext{
${ }^{8}$ Lehmann (1995: 32): 'With increasing grammaticalization [...] the auxiliary loses its inchoative meaning and becomes a mere carrier of finite verbal categories.' For more details, see Jones (2009).

${ }^{9}$ The specialization of the function of sein in the modern German passive may be classed as an example of 'obligatorification', a concomitant of grammaticalization whereby optional forms tend to become obligatory (see Lehmann (1995)).
} 
Many of the criteria for grammaticalization suggested by previous research on Old English passives are not entirely conclusive. For example, it has been suggested (e.g. Denison 1993: 423; Petré \& Cuyckens 2009: 352) that the appearance of passives with a telic, eventive sense, especially as indicated by the presence of temporal adverbials, may indicate grammaticalization. However, such eventive interpretations occur even in adjectival participial constructions, and are therefore not diagnostic of the grammaticalization of the copular construction itself. The following example shows that a passive participle used adjectivally could be modified by a temporal adverb to produce a construction with a telic eventive meaning:

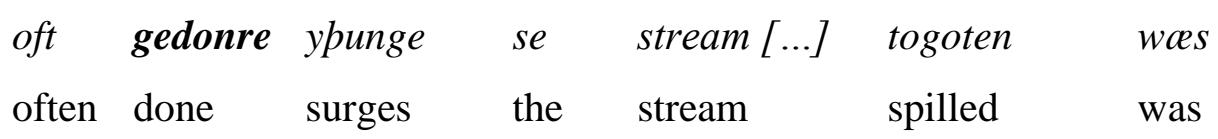

'With frequent surges the stream was poured out.'

$(G D(C)$ III 9.192.14)

It has also been suggested that a criterion for grammaticalization is the avoidance of coordination between passive participles and adjectives in copular constructions; Petré (2014: 122) asserts that such coordination is found only with weorðan and never with wesan, and suggests that this indicates a greater degree of grammaticalization in the case of wesan. However, such an assertion is difficult to reconcile with examples such as the following:

seo was $\partial a[\ldots]$ grene \& fager \& mid [...] blostmum [...] afed \& gegyred it was then green and fair and with blossoms fed and readied 'It was then green and fair and nourished and bedecked with flowers.'

(Bede I 7.38.24)

Given the extreme infrequency of such coordinated constructions with any copula (see Petré 2014), it is possible that any an apparent disparity between copulas might be an artefact of corpus structure.

The presence or absence of agreement between subject and participle has also been suggested as an indicator of grammaticalization. The underlying premise is that constructions with inflected participles, which formally resemble adjectives, share the generally non-eventive 
semantics of adjectival constructions, while eventive passives, being less similar semantically to adjectival constructions, tend to lose their inflections as they became grammaticalized. A review of earlier literature is provided by Mitchell (1985, I, 313-4); this question has also been raised in more recent work (e.g. Petré 2014: 118-9). However, the diagnostic value of participle agreement is open to question. As Mitchell observes (ibid.), it is difficult to find any correlation between participle agreement and eventive semantics, as can be seen from the following pairs:

$\begin{array}{lllll}\text { a. hie wurdon begen afslagen } & \text { atsemne } \\ \text { they became both } & \text { together slain }\end{array}$

'They were both slain together.'

(Or VI 22.144)

\begin{tabular}{|c|c|c|c|c|}
\hline $\begin{array}{l}\mathrm{Her} \\
\text { here }\end{array}$ & $\begin{array}{l}\text { twaegen } \\
\text { two }\end{array}$ & $\begin{array}{l}\text { aldormen } \\
\text { aldermen }\end{array}$ & $\begin{array}{l}\text { wurdon } \\
\text { became }\end{array}$ & $\begin{array}{l}\text { ofslagene } \\
\text { slain }\end{array}$ \\
\hline
\end{tabular}

(ChronE 822.1)

$\begin{array}{lllllll}\text { a. heo begen weeron [...] } & \text { wel gelared } & & \\ \text { they } & \text { both were } & \text { well taught } & & \\ \text { ge } & \text { on } & \text { godcundum } & \text { gewreotum ge in } & \text { weoruldcundum } \\ \text { and } & \text { on godly } & \text { writs } & \text { and in } & \text { worldly }\end{array}$

'They were both well educated, both in godly and in worldly writings.'

(Bede IV 2.258.11)
b. heora discipulas waron wel gelarde
their disciples were well taught

$\begin{array}{llllll}\text { ge in } & \text { Grecisc } & \text { gereorde } & \text { ge in Ladenisc } \\ \text { and in } & \text { Greek } & \text { speech } & \text { and in } & \text { Latin }\end{array}$

'Their disciples were well educated both in Greek and in Latin.'

(Bede IV 2.258.16)

As these examples show, inflected and uninflected participles could occur in very similar constructions, both in eventive and in stative uses. Moreover, participial inflection is found in the passives of many modern Romance languages, even where eventive meaning is present, and 
this is not necessarily viewed as an indicator of ungrammaticalized status. The existing evidence for Old English may not seem to justify adopting a different stance in the present case.

Another criterion often mentioned is the appearance of overtly expressed agents in passive constructions (e.g. Denison 1993: 423, Petré 2014: 119). However, overt agents could also appear in other types of participial constructions:

Pa aras se baddryda unbunden fram Petre
then arose the bedrid unbound from Peter
'Then the invalid arose, unbound by Peter.'

(AELS 9.45)

The existence of such overt agents even in non-copular constructions with a stative, resultative meaning calls into question the association sometimes proposed between such agents and telic transitivity (e.g. Petré \& Cuyckens 2009). It has long been observed that Old English expressed agency using a wide variety of prepositions whose exact shade of meaning may be difficult to determine (e.g. Mitchell 1985: I, 334-48), giving rise to the suggestion that the expression of agency in Old English was not fully grammaticalized (e.g. Kilpiö 1989: 166). Nevertheless, within the framework of the present study the increasingly regular expression of agency in passives in the development of English might better be regarded as constructionalization rather than grammaticalization. Even in Modern English, unless a strictly transformational analysis of passives is adopted (e.g. Lightfoot 1979), there is no need to suppose that agent phrases with by are more closely connected to the verbal component of a passive than any other adverbial adjunct; if passive constructions do not express the agent of an event, and if the preposition by can express agency independently of a verb (e.g. a play by Shakespeare), the semantic fit between the two elements would in itself ensure their frequent collocation. According to such an analysis, the greater systematicity of agent phrases in Modern English passives would be the result of a superficial change not directly related to any changes in the copular constructions themselves. The difficulty of using visible changes of this sort as unambiguous indicators of morphosyntactic processes suggests that the existing evidence is not sufficient to establish conclusively the existence of grammaticalization in OE passive constructions. 


\section{THE SEMANTIC MODEL}

\subsection{DEFINITION OF TERMS USED IN THE SEMANTIC MODEL}

Our semantic model is built around two types of situation: non-transitional and transitional. ${ }^{10} \mathrm{OE}$ copular verbs and passive participles can be analysed in terms of such situations, as can the combinations between them.

A verb (or verb phrase) is non-transitional if it does not denote a situation that involves a transition from one discrete state of affairs to another. For example, the verbs 'to contain', 'to wait', 'to carry', 'to walk' are non-transitional. Non-transitional verbs may denote either states, e.g. 'to contain', 'to wait', or events, e.g. 'to carry', 'to walk'.11

A verb (or verb phrase) is transitional if it denotes a situation that involves a transition from one situation to another. For example, the verbs 'to open', 'to break', 'to darken', 'to multiply' are transitional. Transitional verbs may denote either telic events (i.e. necessarily containing an end-point), as in 'to open', 'to break', or atelic events (i.e. not necessarily containing an end-point), e.g. 'to darken', 'to multiply'. 12

A non-transitional verb can be made transitional by the addition of an adverbial or prepositional phrase. For example, 'to carry' and 'to walk' on their own are non-transitional, but 'to carry (something) to (somewhere)' and 'to walk to (somewhere)' are transitional. In our

\footnotetext{
${ }^{10}$ The semantic model proposed here for OE is similar to that set out in Jones (2009) for OHG.

${ }^{11}$ On the difference between states and events we follow Comrie (1976: 48), for whom events require 'dynamism'.

${ }^{12}$ Our non-transitional situations combine the categories of States and Processes as found in Pustejovsky (1991) and our transitions correspond to Pustejovsky's Transitions category. For a similar separation, this time between 'terminative' and 'non-terminative' verbs, see Nedjalkov and Jaxontov (1988). As our examples illustrate, the situation out of which the transition takes place is the complement (i.e. absence) of the situation into which the transition takes place. For example, 'to redden' denotes a transition from less red to redder rather than from some other specific quality to red.
} 
model we consider the whole predicate, including any adverbial and prepositional phrases, when deciding whether it is transitional or non-transitional. ${ }^{13}$

In the table below we show how the verbs which we have just cited as 'transitional' or 'non-transitional' relate to the commonly used semantic categories of 'stative', 'atelic eventive', and 'telic eventive'.

\begin{tabular}{|l|c|c|}
\hline & Non-transitional & Transitional \\
\hline Stative & contain, wait & - \\
\hline Atelic Eventive & carry, walk & darken, multiply \\
\hline Telic Eventive & - & open, break \\
\hline
\end{tabular}

TABLE 1. Situation types and verb types.

As the table makes clear, atelic eventive verbs (sometimes called 'process' or 'activity' verbs) may be either non-transitional or transitional. ${ }^{14}$

\subsection{THE MEANING OF WEORĐAN, WESAN/BEON, AND THE PASSIVE PARTICIPLE}

Our semantic model of the combination of weorðan or wesan/beon and a passive participle is intended to establish whether the meaning of the construction is compositional; that is, whether its meaning can be deduced from the composition of the meaning of its constituent parts. To do this, we start by defining the meaning of the copulas and passive participles in Old English when they are not used together.

We are interested in the lexical meaning of weordan or wesan/beon, that is, the meaning which remains constant whatever the grammatical category (person, number, tense, mood) in which the verb is used. In general terms, weorðan predicates a transition and corresponds to PDE (Present-Day English) 'to become'. Apart from its subject complement, it is formed with a

\footnotetext{
${ }^{13}$ On the interplay between sentence constituents in the determination of Aktionsart categories, see Verkuyl (1972) and Dowty (1972).

${ }^{14}$ A widely used classification in the literature is that of Vendler (1967), who subdivides eventive telic verbs into 'accomplishment' and 'achievement' verbs. Accomplishment verbs denote telic situations in which there is a culmination up to and including a transition point (e.g. 'to open'), whereas achievement verbs denote only the transition point (e.g. 'to break'). For a summary of later classifications, see Verkuyl (1993).
} 
predicative complement which may be a phrase headed by an adjective, noun, present participle, or a prepositional/adverbial phrase. ${ }^{15}$ The transition is typically into a state (e.g. he wearð yrre 'he became angry'), but can also be into a non-transitional event, e.g. he wearð cwepende ( $\approx$ 'he began to speak'). ${ }^{16}$ We have not been able to find examples in which weorðan predicates a transition into a situation which must itself be read as transitional, such as *he wearð onginnende $\left(\approx\right.$ 'he came to begin'). ${ }^{17}$

The verb wesan/beon predicates existence, and corresponds to PDE 'to be'. As well as a subject complement, it is formed with a predicative complement which defines the situation in which the subject exists or the quality of the subject which is asserted. Wesan/beon can take a state as its predicative complement (e.g. wesan cwicu 'be alive') but it can also take an event, which may be transitional or non-transitional, e.g. hio is cennende pa fulcupan wildeora 'she is begetting the familiar beasts' (Alex 3.5); ${ }^{18}$ hwilum waes on horse sittende, ac oftor on his fotum gangende 'sometimes he would ride on horseback, but more often would walk on foot' (Bede IV 28.362.17).

The lexical meanings of weorðan and wesan/beon can thus be summarized in terms of Aktionsart categories: weorðan predicates the transition into a non-transitional situation and wesan/beon predicates the existence of any situation, transitional or non-transitional.

As for passive participles, their lexical meaning depends on that of the verbs from which they are derived. However, like weorðan and wesan/beon they can be analysed in broad Aktionsart categories based on transitions and non-transitional situations. For the meaning of passive participles outside constructions with weorðan or wesan/beon we rely on their use as attributes. We start by making a distinction between passive participles which come from non-

\footnotetext{
${ }^{15}$ See Bosworth-Toller for examples.

${ }^{16}$ See Visser 1973: 1918.

${ }^{17}$ In early $\mathrm{OE}$, there is a clear (but not absolute) semantic contrast between weorðan and geweorðan, which means 'come into being, happen', as in this example: he [...] saede ðatte sua geweard 'he said what had happened thus' (CP 43.311). In late Old English this distinction becomes increasingly blurred, and forms with and without the prefix are frequently used in both senses.

${ }^{18}$ The wesan + present participle construction may mark imperfective or habitual aspect, in contrast to unmarked simplex forms.
} 
transitional verbs and those which come from transitional verbs. Those that come from nontransitional verbs are themselves always non-transitional, as in the following examples;

PASSIVE PARTICIPLES FROM NON-TRANSITIONAL VERB

$\begin{array}{llll}\text { Hie }[\ldots] & \text { on } & \text { wuldre geweorpode } & \text { rixiap } \\ \text { they } & \text { in } & \text { glory honoured reign }\end{array}$

'They reign, honoured in glory'

(BlHom 15.171.26)

$\begin{array}{llll}\text { hi becomon } & \text { to } & \text { sumum anlicum felda fagre geblowen } \\ \text { they arrived } & \text { to } & \text { some singular } & \text { field fairly blown }\end{array}$

'Blown fairly, they came to a singular field.'

(AELS 21.351)

These examples show, respectively, that the non-transitional passive participle can be either stative or eventive.

By contrast, passive participles from transitional verbs may be read as transitional or nontransitional (the latter corresponding to the category 'resultative'). Here are examples with the passive participle of don:

PASSIVE PARTICIPLES FROM TRANSITIONAL VERB

(11) Transitional passive participle:

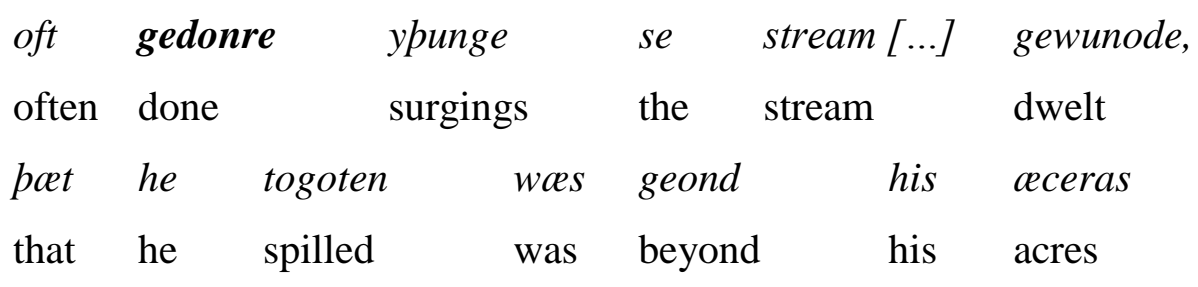

'With frequent surges the stream was accustomed to be poured out beyond his fields.' $(G D(C)$ III 9.192.14, repeated from 4 above)

(12) Non-transitional (i.e. resultative) passive participle hit $[\ldots] \partial a \quad$ gedonan synna aweg aðwiehð 
it the done sins away washes

'It washes away the committed sins'

(CP 36.257.19)

These examples suggest that the passive participle of transitional verbs represents a complex event structure, which includes (i) a transition, as in 11, and (ii) a non-transitional situation, as in 12 ; this is illustrated in the figure below.

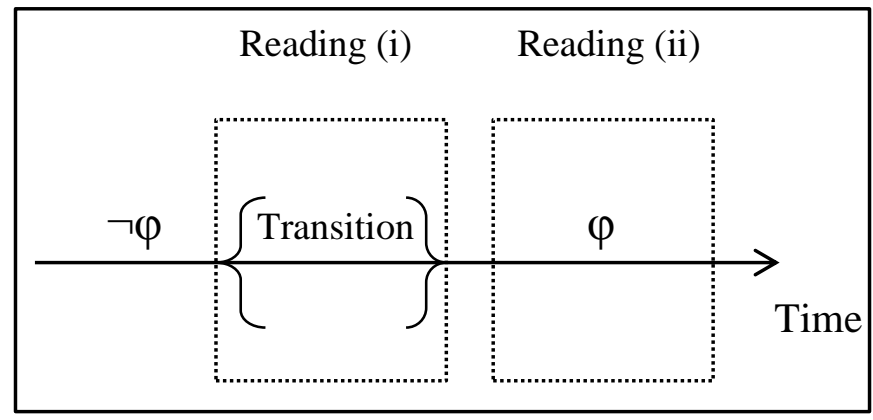

FIGURE 1. The event structure of passive participles of transitional verbs

Reading (i) corresponds to example (11) above, in which the complex event structure is evaluated during the transition into $\varphi$. Reading (ii) corresponds to example (12) above, in which the complex event structure is evaluated during $\varphi$. Even though each reading evaluates a different phase of the complex event, it does not detach that phase from the rest of the event structure. Thus, under reading (i) it is understood that the transition is into situation $\varphi$, and under reading (ii) it is understood that situation $\varphi$ arose from a transition. In other words, $\varphi$ is a resultant state and not merely a state. ${ }^{19}$

\subsection{THE INTERACTION BETWEEN WEORĐAN OR WESAN/BEON AND PASSIVE PARTICIPLE}

\footnotetext{
${ }^{19}$ For a similar analysis of the Old High German passive participle, see Abraham (1991). For a detailed treatment of the difference between various types of resultatives (active and passive) and between 'resultatives proper' and statives, see Nedjalkov (2001).
} 
In this section we set out a model for the interaction between copular verb and passive participle in OE passive constructions in which each component brings into passive constructions the same semantics and combinatorial constraints as it has outside the passive.

Based on our analysis above of the use of weorðan outside passive constructions, we posit that it demands a predicative complement which denotes a non-transitional situation, and that the combination refers to a transition into that situation. When that predicative complement is a passive participle from a non-transitional verb, the interaction is straightforward. For example, wearð сиð means 'became/began to be known', and wearð geblowen means 'became/began to be blown'; these two examples illustrate that the non-transitional passive participle may be stative or eventive.

When weorðan combines with the passive participle of a transitional verb, the analysis is less straightforward because, as we show in section 3.2, such passive participles have two possible readings. However, since (according to this model) weorðan demands a non-transitional predicative complement, only reading (ii) is applicable. The combination therefore predicates the transition into a resultant state (symbolized by $\varphi$ in Figure 1). For example, wearð gedon means 'became/got done'. Based on our analysis of usage outside passive constructions, we posit that wesan/beon is free to combine with both non-transitional and transitional predicative complements, and predicates the existence of the subject in whatever situation is denoted by that complement. When wesan/beon combines with the passive participle of a non-transitional verb, it merely predicates that the subject is in that non-transitional situation; thus waes cuð means 'was known', and waes geblowen means 'was blown' (notice again that the non-transitional passive participles may be stative or eventive). When wesan/beon combines with the passive participle of a transitional verb, either of the readings in Figure 1 is applicable. Accordingly, unless disambiguated by the context, woes gedon can mean 'became/got done' (reading (i)) or 'was done' (i.e. 'was already done' — reading (ii)).

We set out in Panel A of Table 2 the relationship between the Aktionsart of the lexical verb from which the passive participle is formed, the Aktionsart of the passive participle itself, and the Aktionsart of the combination of copular verb + passive participle. The first two columns summarize our analysis of passive participles in the preceding section, namely that the passive participles of non-transitional ('NT') verbs are themselves always non-transitional, but the passive participles of transitional (' $T$ ') verbs may be either transitional or non-transitional. In the 
third column we allow for the passive constructions to be NT or T, whatever the Aktionsart of the lexical verb from which the passive participle is formed. The column 'shorthand notation' summarizes these combinations in a single term; for example, ' $\mathrm{NT}^{\mathrm{T}}$ ' tells us that the Aktionsart of the combination is non-transitional and that the passive participle comes from a verb with transitional Aktionsart. In Panel B we repeat the shorthand notation and show which copular $\operatorname{verb}(s)$ would, under our model, be expected to realize a passive construction which falls into that Aktionsart category. For three of the Aktionsart categories we expect passive constructions to be formed with one copular verb but not the other, but we expect passives in the category $\mathrm{T}^{\mathrm{T}}$ to be formed with either copula.

\begin{tabular}{|c|c|c|c|}
\hline Panel A & & & \\
\hline & Aktionsart of... & & \\
\hline $\begin{array}{c}\text { underlying lexical } \\
\text { verb }\end{array}$ & $\begin{array}{c}\text { pass. part. of lexical } \\
\text { verb }\end{array}$ & $\begin{array}{c}\text { combination of } \\
\text { copula + pass. part. of }\end{array}$ & Shorthand notation \\
\hline NT (e.g. cunnan) & NT (e.g. $c u ð)$ & NT & $\mathrm{NT}^{\mathrm{NT}}$ \\
\hline NT (e.g. cunnan) & NT (e.g. cuð) & $\mathrm{T}$ & $\mathrm{T}^{\mathrm{NT}}$ \\
\hline $\mathrm{T}$ (e.g. don) & T or NT (e.g. gedon) & NT & $\mathrm{NT}^{\mathrm{T}}$ \\
\hline $\mathrm{T}(\mathrm{e} . \mathrm{g} . d o n)$ & T or NT (e.g. gedon) & $\mathrm{T}$ & $\mathrm{T}^{\mathrm{T}}$ \\
\hline
\end{tabular}

\begin{tabular}{|c|l||l|}
\hline \multicolumn{2}{|l|}{ Panel B } \\
\hline $\begin{array}{c}\text { Shorthand } \\
\text { notation }\end{array}$ & $\begin{array}{c}\text { Expected } \\
\text { copular verb }\end{array}$ & \multicolumn{1}{|c|}{ Examples } \\
\hline $\mathrm{NT}^{\mathrm{NT}}$ & wesan/beon & woes cuð \\
\hline $\mathrm{T}^{\mathrm{NT}}$ & weorðan & wearð cuð \\
\hline $\mathrm{NT}^{\mathrm{T}}$ & wesan/beon & waes gedon \\
\hline $\mathrm{T}^{\mathrm{T}}$ & either & waes/wearð gedon \\
\hline
\end{tabular}

' $\mathrm{T}$ ' = transitional; 'NT' = non-transitional; $\mathrm{NT}^{\mathrm{T}}$ etc = Aktionsart of the combination is nontransitional and passive participle comes from underlying verb with transitional Aktionsart, etc.

TABLE 2. Combinations between copula verb and passive participle.

We now explain these interactions in more detail.

- If $\mathrm{NT}^{\mathrm{NT}}$ expect wesan/beon. If the Aktionsart of the combination is non-transitional and the passive participle comes from a non-transitional verb such as cunnan or blawan, we expect the copula to be wesan/beon (if the copula were weorðan this would force a transitional meaning). 
- If $\mathrm{T}^{\mathrm{NT}}$ expect weorðan. If the Aktionsart of the combination is transitional and the passive participle comes from a non-transitional verb such as cunnan or blawan, we expect the copula to be weorðan. We call this category 'ingressive' (if the copula were wesan/beon both parts of the combination would be non-transitional).

- If $\mathrm{NT}^{\mathrm{T}}$ expect wesan/beon. If the Aktionsart of the combination is non-transitional and the passive participle comes from a transitional verb such as don, we expect the copula to be wesan/beon. We call this category 'resultative' (if the copula were weorðan this would force a transitional meaning).

- If $\mathrm{T}^{\mathrm{T}}$ expect either copula. If the Aktionsart of the combination is transitional and the passive participle comes from a transitional verb such as don, we expect either copula. Because these constructions denote transitional events, it is possible to use either wesan, with transitionality expressed by the participle, or weorðan, with transitionality expressed by the copula.

\section{Methodology}

The texts analysed were all drawn from the York-Toronto-Helsinki Parsed Corpus of Old English Prose (Taylor et al. 2003). Preference was given to texts translated from Latin, so that we could use the original to help resolve ambiguities in the Old English texts; this criterion would rule out most of the surviving Old English poetic corpus, and so the present study has concentrated upon prose texts. We cite individual texts by the customary short titles (see Mitchell et al. 1975). References within the texts are given in a format based on that of the Corpus; the line numbers given in the Corpus generally refer to the beginning of the paragraph, which may not correspond exactly to the passage being cited.

Owing to the amount of manual analysis required, only a subset of the Corpus was analysed; it will be seen that this was still sufficient to provide significant results. A starting point for the sampling methods was the corpus used in Macleod (2014), a methodologically similar study; however, alterations have been made to this schema where appropriate, as we 
explain below. Texts were chosen to represent a mix of different time periods and stylistic diversity. One of the earlier texts included is the Cura Pastoralis $(C P)$, which dates from the late 9th century (e.g. Sweet 1871). For this text the same sample as in Macleod (2014) was used, comprising the preface and Chapters 1-5, 21, 32-6, and 50-4. The Latin text used for comparison was taken from the edition of Judic \& Rommel (1992). A text that presented additional complications in terms of sampling was Bede's History (Bede), which also dates from the late 9th century (see Whitelock 1962: 57-9). The constructions with weorðan are unusually infrequent in this text, a phenomenon that will be examined below, and as a result the sample from Macleod (2014) was extended to include the full text of all sections containing passives with weorðan; this comprises the preface, Chapter 7 of Book 1, Chapters 3-10 and 16 of Book 2, Chapter 20 of Book 3, Chapters 1-3, 17, 23 and 32 of Book 4, and Chapters 12-13 of Book 5. For this text, the Latin version was taken from the edition of Plummer (1896). Another early text included is the history of Orosius (Or), dating from the late 9th or early 10th century (see Bately 1980: 1xxxvi-xciii). In this case a different sampling method was used, to ensure a larger and more even sample; every fifth chapter was taken in its entirety, starting from Book 1, Chapter 2, in order to avoid the interpolated material in the first chapter. For the Latin text the edition of Sweet (1883) was used; this was designed for comparison with the Old English translation, which is relatively free, and omits the many passages which lack any counterpart in the Old English text. In some passages the Latin text presents certain difficulties of interpretation, and when in doubt we followed the reading of Fear (2010). The Dialogues of Gregory the Great $(G D)$ were included in both versions: MS C, containing the original version from the end of the 9th century, and MS H, a partial revision made at least a century later (see Yerkes 1986); for each manuscript Book I, the only book to be preserved fully in both of them, was analysed in its entirety.

Other texts from a later period that were analysed include Ælfric's translation of the Old Testament, which was composed around the end of the 10th century. The existing text is thought to be a conflation of work by Ælfric and another translator, and the sample used here was restricted to the passages for which Ælfric's authorship seems most certain, namely Genesis 1:13:24, 6:1-9:29, 12:1-14:20, and 22:1-22:19; Numbers 13:1-14:45, 16:1-17:11, and 18:1-21:18; and Joshua 2:1-7:26 (see Clemoes 1966). The Latin text used for comparison was that of the Vulgate; although modern editions of the Vulgate may not correspond exactly to the texts in use 
in Anglo-Saxon England, none of the known textual differences would affect the passages at issue here (see Marsden 1995: 395-419). Another text from the late 10th century, which was not included in the study by Macleod (2014), is Æthelwold's translation of the Benedictine Rule (see Gretsch 1992). Of this work the first 20 chapters were analysed; due to the structurally repetitive nature of the text this was found sufficient to provide a representative sample. The Latin text for comparison was taken from the edition of Schmitz (2009). In order to make sure that later periods of Old English were adequately represented, two texts without Latin equivalents were also included, Wulfstan's Homilies and MS E, the Peterborough manuscript, of the Anglo-Saxon Chronicle. Wulfstan's Homilies (WHom), which were composed in the late 10th or early 11th century (see Bethurum 1957), are sometimes accompanied by Latin material, ranging from collections of Biblical and patristic quotations incorporated into the vernacular homily to a separate Latin homily on a similar theme; however, there is too little similarity between the Latin material and the Old English text for meaningful comparison. All the Old English homilies were analysed in their entirety. The sample used of the Chronicle (ChronE) includes the annals from 966-1121, representing the Old English portion of the text unique to this manuscript (for a discussion of the composition of the text, see Irvine 2004: xviii-xxiii); the text thus represents one of the few available sources of Old English data from the 11th and 12th centuries.

Automated syntactic queries were performed using the CorpusSearch software package (Randall 2010), supplemented by manual searches for specific strings. Once potential tokens of relevant verb forms were identified, they were examined in context in order to establish the most probable Aktionsart reading. Where ambiguity existed regarding the Aktionsart of the Old English construction, the original Latin construction could sometimes provide cues as to the intended meaning, and the Latin Aktionsart was also recorded; however, it will be seen that in some instances there were unambiguous differences between the two. The Aktionsart category of the construction and the choice of copula were the two main variables; as described above, the presence or absence of associations between Aktionsart and copula can test our hypotheses regarding the semantic properties of the two types of construction and their grammaticalization. In addition to these, other properties of the Old English and Latin constructions that might be potential variables in the choice of copula were also examined; these will be described in greater detail below. Latin passives which were not translated by an Old English passive form were also 
noted, in order to determine whether the avoidance of the passive in Old English was systematic in ways which might throw light on the choice of copular verb.

\section{RESULTS}

\subsection{THE COMPOSITIONAL MODEL}

The associations between the copulas and the different types of situation predicted by the compostional model, which were set out in Table 2, are recapitulated below.

\begin{tabular}{|r|c|c|}
\cline { 2 - 3 } \multicolumn{1}{c|}{} & weorðan & wesan \\
\hline $\mathrm{NT}^{\mathrm{NT}}$ & No & Yes \\
\hline $\mathrm{T}^{\mathrm{NT}}$ & Yes & No \\
\hline $\mathrm{NT}^{\mathrm{T}}$ & No & Yes \\
\hline $\mathrm{T}^{\mathrm{T}}$ & Yes & Yes \\
\hline
\end{tabular}

Table 3: Expected Distributions of Copulas

The Aktionsart categories $\mathrm{T}^{\mathrm{NT}}$ and $\mathrm{T}^{\mathrm{T}}$ (that is, transitionals) are the only ones in which weorðan is expected to occur, while wesan is expected to occur everywhere except for the Aktionsart category $\mathrm{T}^{\mathrm{NT}}$ (that is, except for ingressives). The actual distributions of the two copulas are as follows:

\begin{tabular}{|r|l|l|}
\cline { 2 - 3 } \multicolumn{1}{c|}{} & \multicolumn{1}{c|}{ weorðan } & \multicolumn{1}{c|}{ wesan/beon } \\
\hline $\mathrm{NT}^{\mathrm{NT}}$ & $0.00 \%(\mathrm{n}=0)$ & $100.00 \%(\mathrm{n}=285)$ \\
\hline $\mathrm{T}^{\mathrm{NT}}$ & $71.43 \%(\mathrm{n}=5)$ & $28.57 \%(\mathrm{n}=2)$ \\
\hline $\mathrm{NT}^{\mathrm{T}}$ & $0.00 \%(\mathrm{n}=0)$ & $100.00 \%(\mathrm{n}=134)$ \\
\hline $\mathrm{T}^{\mathrm{T}}$ & $26.61 \%(\mathrm{n}=318)$ & $73.39 \%(\mathrm{n}=877)$ \\
\hline
\end{tabular}

Table 4: Actual Distributions of Copulas

The actual distribution seen in these results conforms almost exactly to that predicted by the compositional model. There is no evidence of any extension of weorðan to non-transitional constructions; instead, all of these use wesan/beon, whether they are $\mathrm{NT}^{\mathrm{NT}}$ or $\mathrm{NT}^{\mathrm{T}}$, as in the two following examples, respectively:

$\begin{array}{lllllll}\text { (13) se halga } & \text { man } & \text { was } & \text { fram } & \text { eallum } & \text { mannum } & \text { gelufod } \\ \text { the holy } & \text { man } & \text { was } & \text { from } & \text { all } & \text { men } & \text { loved }\end{array}$


'The holy man was loved by all.'

$(G D(\mathrm{C}) \mathrm{I} 2.21 .7)$

$\begin{array}{lllll}\text { Ic eom } & \text { gebiged aghwor } & \text { and } & \text { genyperad. } \\ \text { I am } & \text { abased everywhere } & \text { and } & \text { lowered }\end{array}$

'I am everywhere abased and brought low.'

(BenR 7.31.16)

Similarly, as predicted, both copulas occur in transitional constructions:

$\begin{array}{llll}\text { Par weard } & \text { ofslagen Eadnoð } \\ \text { there } & \text { became slain } & \text { Ednoth }\end{array}$

'Then Ednoth was slain.'

(ChronE 1016.81)

$\begin{array}{lllll}\text { on pisum } & \text { geare } & \text { was } & \text { Eadric ealdormann } & \text { ofslagen } \\ \text { in this } & \text { year } & \text { was } & \text { Edric alderman } & \text { slain }\end{array}$

'In this year Alderman Edric was slain.'

(ChronE 1017.4)

The only way in which our results deviate from those predicted is in the distribution of ingressives, transitional constructions involving non-transitional verbs. The majority of these are indeed formed with weorðan, as in the following example:

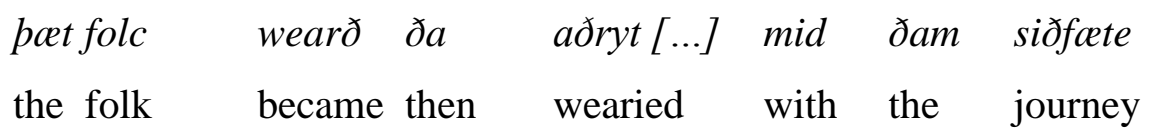

'The people then became wearied with the journey.'

(Num 21:4)

The ingressive sense of this example can be seen from the fact that it was used to translate a Latin construction with coepi 'begin' (taedere coepit populum itineris). The only unambiguous examples of ingressives formed with wesan involve the praesens subjunctive: ${ }^{20}$

\footnotetext{
${ }^{20}$ We use Latin terms for some tense forms to distinguish them from time references, for which English terms such as 'present' and 'future'; see 'Tense and time reference' below.
} 


$$
\begin{aligned}
& \text { sy pe pis cup } \\
& \text { be thee this known }
\end{aligned}
$$

'Let this be known to you.'

$(G D(\mathrm{C}) \mathrm{I}: 9.65 .25)$

In these examples the jussive context provides a sufficient cue to prevent the construction from being seen as referring to an ongoing state, and there is thus no need to mark the ingressive meaning through the use of an inherently transitional copula.

The foregoing results suggest that the compositional model can account for much of the variation between wesan and weorðan in terms of the semantic contributions of the copula and participle and therefore that there is no evidence of grammaticalization. Moreover, since wesan is widely used in $\mathrm{NT}^{\mathrm{NT}}, \mathrm{NT}^{\mathrm{T}}$, and $\mathrm{T}^{\mathrm{T}}$ constructions, there is no evidence of constructionalization either. However, even though both copulas are used for constructions of the $\mathrm{T}^{\mathrm{T}}$ type (as the model predicts), the distributions of the two are not equal; in this category wesan predominates, a phenomenon that might provide preliminary support for the hypothesis that weorðan was the more marked form.

A number of additional variables were analysed in the present study to assess the strength of their association with a particular copula, which might indicate further semantic or syntactic differences between the two. These include the Aktionsart of the verb phrase and the tense and mood of the Old English verb, as well as the nature of the translation from Latin to English. While the data above have been used to establish the validity of the compositional model, these additional variables may provide data on the distribution of the copulas within the limits made possible by such compositional semantics.

\subsection{FURTHER AKTIONSART ANALYSIS}

In order to ensure that the results presented above do not derive from the use of relatively broad categories masking subtler distinctions, we also analysed the data using a more finely detailed model of Aktionsart. First of all, we divide the eventive category into telic eventives (which necessarily denote an endpoint) and atelic eventives (which do not). We also subdivide statives into two subcategories, namely 'Kimian' and 'Davidsonian' statives. Kimian statives denote 
states which are accessible only to cognitive faculties and not to sensory perception, and they can be situated in time, but not in space; examples include 'to know' and 'to own'. Davidsonian statives, by contrast, denote states which are accessible to both cognitive faculties and sensory perception and which can be situated in both time and space; examples include 'to wait' and 'to sleep' (see Rothmayr 2009 for further details and diagnostics to tell these categories apart).

A more detailed breakdown of the Aktionsart of verb phrases, using the categories defined above, can be seen below.

\begin{tabular}{|c|c|c|}
\hline & weorðan & wesan/beon \\
\hline Telic eventive $\left(\mathrm{T}^{\mathrm{T}}\right)$ & $27.40 \%(\mathrm{n}=311)$ & $72.60 \%(\mathrm{n}=824)$ \\
\hline Atelic eventive $\left(\mathrm{T}^{\mathrm{T}} / \mathrm{NT}^{\mathrm{NT}}\right)$ & $7.50 \%(n=6)$ & $92.50 \%(n=74)$ \\
\hline Kimian resultative $\left(\mathrm{NT}^{\mathrm{T}}\right)$ & $0.00 \%(\mathrm{n}=0)$ & $100.00 \%(\mathrm{n}=134)$ \\
\hline Other Kimian stative $\left(\mathrm{NT}^{\mathrm{NT}}\right)$ & $0.00 \%(\mathrm{n}=0)$ & $100.00 \%(\mathrm{n}=156)$ \\
\hline Davidsonian stative $\left(\mathrm{NT}^{\mathrm{NT}}\right)$ & $0.00 \%(\mathrm{n}=0)$ & $100.00 \%(\mathrm{n}=111)$ \\
\hline Ingressive $\left(\mathrm{T}^{\mathrm{NT}}\right)$ & $71.43 \%(n=5)$ & $28.57 \%(\mathrm{n}=2)$ \\
\hline Ambiguous & $1.58 \%(\mathrm{n}=6)$ & $98.42 \%(n=374)$ \\
\hline
\end{tabular}

Table 5: Aktionsarten of Copular Constructions

As can be seen, weorðan is found not only in telic eventive constructions, but also in a small number of atelic constructions. These are all transitional constructions, such as the following:

Men wurdon Ja gemenigfylde ofer eorðan
men became then multiplied
'Men were then multiplied over the earth.'
(Gen 6:1)

A verb such as manigfealdan 'multiply' denotes a change from one situation to another, even if no specific endpoint is implied. Unlike weorðan, wesan is also found in non-transitional atelic constructions:

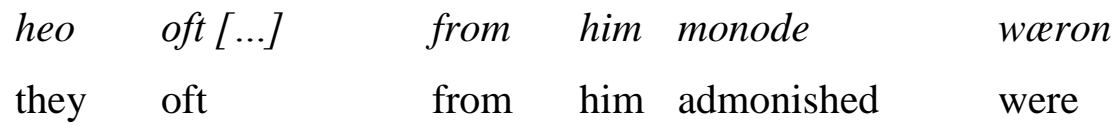

'They were often admonished by him.'

(Bede II 5.112.19)

This is compatible with a semantic model in which wesan, unlike weorðan, does not necessarily entail a transitional reading. The data also show that many more ambiguous constructions are recorded with wesan than with weorðan; this is consistent with the semantics of wesan allowing 
for a degree of ambiguity between eventive and stative readings which is not present with weorðan, and is in line with our compositional model as set out in section 3.2.

Para monna was siex $M, \quad$ pa hie gegaderad waron the men's was six thousand, when they gathered were 'There were six thousand of the men, when they were gathered.' (Oros IV 9.102.9)

A sentence such as the above is ambiguous between an eventive reading ('when he had gathered them') and a stative reading ('when they were together'). As the distribution of the finer Aktionsart categories used in this analysis tallies so closely with what was seen with the broader categories above, it would seem that the variation occurring within the bounds of the compositional model must be due to other factors than Aktionsart.

\subsection{FURTHER ANALYSIS}

\section{ASPECT AND TRANSLATION PRACTICES}

A detailed analysis of the ways in which different Latin tense forms are rendered into Old English has already been provided by Kilpiö (1989) for the texts included in his study. However, an examination of translation practices provides the opportunity to explore additional variables such as aspect. Aspect categories, in contrast to Aktionsart categories, correspond to the different ways in which speakers view the same situation in the world. The main aspectual categories which we use in this paper are 'perfective' and 'imperfective'. A speaker who uses a verb in the perfective aspect chooses to present a given situation as a complete whole, while one who uses the imperfective aspect sees the same situation as incomplete. The distinction corresponds broadly to the following pairs in PDE and Latin: I closed the doorlianuam claudivi (perfective) and I was closing the door/ianuam claudiebam (imperfective). ${ }^{21}$ Some accounts (e.g.

\footnotetext{
${ }^{21}$ Note that perfective and imperfective forms can have different degrees of markedness. For example, the PDE simple past 'I closed the door' is, arguably, unmarked for aspect, and can be used interchangeably with the
} 
Comrie 1976) subdivide the 'imperfective' category more finely. The only subdivision which we use in the empirical analysis is 'iterative', in which a situation is viewed as repeated, as in PDE he kept closing the door. ${ }^{22}$ Although we treat Aktionsart and aspect as separate categories, they can interact. In particular, the use of an otherwise telic eventive verb in the imperfect aspect can coerce that verb into being atelic. For example, 'to close' would, in most treatments of Aktionsart, be classed as telic eventive on the grounds that it includes an end-point as part of its lexical meaning, i.e. a complete closure is part of the verb's truth conditions, but in I was closing the door the verb becomes atelic eventive, since complete closure is no longer part of the verb's truth conditions. ${ }^{23}$ When we assign a verb to an Aktionsart category, we do so based on its nonimperfective form; thus we define 'to close' as an eventive telic verb.

Old English lacked grammaticalized aspect (e.g. Mitchell 1985, I, 363-9), but as this category was present in Latin, Old English translators confronted with an aspectually marked Latin form would have been able to take this category into account in choosing a copula. Moreover, even when no translation is involved, the semantic properties denoted by aspect can often be inferred from context. The category of imperfective aspect is considered here to encompass the Latin imperfect and to most examples of the praesens and futurum, while the category of perfective aspect encompasses the perfectum stem as well as any other forms that clearly cannot be construed as referring to an ongoing, incomplete situation (for further discussion of the aspect of the Latin passive, see Jones 2009: 38-40). For the purposes of analysis we have adopted the division of imperfectives into iteratives, denoting multiple situations of the same kind, and continuous imperfectives, denoting only a single situation.

imperfective form in some contexts, e.g. As I closed/was closing the door I shivered. By contrast the PDE imperfective is marked for aspect, so that I was closing the door cannot denote the complete closing of the door. Thus I closed the door, then turned round guarantees that the closure of the door was complete, while I was closing the door, then turned round does not. For a discussion see Comrie (1976: 111-22).

${ }^{22}$ For the possible existence of an iterative Aktionsart, rather than aspect, category, see Jones (2009: $\left.7 \mathrm{ftn}\right)$.

${ }^{23}$ This interaction is often referred to as the 'imperfective paradox' (after Dowty 1977) on the grounds that the meaning of a telic verb is defined in terms of its end-point, but that end-point need not be achieved. On the interaction between Aktionsart and aspect, see Jones (2009: 8-11). 


\begin{tabular}{|c|c|c|}
\hline & weorðan & wesan/beon \\
\hline Perfective & $15.92 \%(n=143)$ & $84.08 \%(n=755)$ \\
\hline Imperfective (Continuous) & $8.05 \%(\mathrm{n}=40)$ & $91.95 \%(n=457)$ \\
\hline Imperfective (Iterative) & $3.54 \%(n=4)$ & $96.46 \%(n=109)$ \\
\hline
\end{tabular}

Table 6: Translation and Aspect

The table above shows only data from translated texts. It can be seen that wesan/beon is used significantly more often to translate imperfective verbs $\left(\chi^{2}(2)=27.10, p<.001\right)$; however, the alignment of the copulas to these aspect categories is not so close as their alignment to the Aktionsart categories of the compositional model presented above. It should be noted that this table includes both transitional and non-transitional constructions; however, as seen above, weorðan is never found in non-transitional constructions, and so this is essentially a comparison of two types of construction involving wesan/beon against a single type of construction with weorðan. Such a comparison has the potential to conflate phenomena resulting from the operation of different variables. The table below shows the same data with the non-transitional examples removed:

\begin{tabular}{|c|c|c|}
\hline & weorðan & wesan/beon \\
\hline Perfective & $22.22 \%(n=134)$ & $77.78 \%(\mathrm{n}=469)$ \\
\hline Imperfective (Continuous) & $22.73 \%(\mathrm{n}=40)$ & $77.27 \%(\mathrm{n}=136)$ \\
\hline Imperfective (Iterative) & $3.92 \%(\mathrm{n}=4)$ & $96.08 \%(\mathrm{n}=98)$ \\
\hline
\end{tabular}

Table 7: Translation and Aspect (Transitional Constructions)

When only transitional examples are included, it can be seen that the difference between perfectives and continuous imperfectives is no longer significant $\left(\chi^{2}(1)=0.02, p>.05\right)$; the more frequent use of wesan/beon for the latter in the previous sample was due to the presence of imperfective statives. However, the increased use of wesan/beon for iteratives remains significant $\left(\chi^{2}(2)=18.99, p<.001\right)$. This may be related to the transitional semantics of weorðan; if the use of weorðan calls attention not merely to the existence of an inherently transitional situation but to the transition by which it takes place, the transition itself may not be the most salient feature of a recurring situation, and therefore a different copula would be used. In the following sections, data are given only for transitional constructions unless otherwise indicated, to allow factors other than Aktionsart to be isolated more easily.

An additional way in which translation can influence the form of texts was suggested by Macleod (2014: 333-6), which found that more literal translations can sometimes display a different general pattern from free translations. In this work a distinction has been drawn 
between passive constructions that are 'strict' translations, in which either the Old English and the Latin correspond in every respect or else only minor changes such as a change of tense or mood have taken place, and those which are 'free' translations, in which the Old English construction translates an active Latin verb or a different syntactic category such as a noun, or does not correspond directly to any Latin form. When data from translated texts was analysed it was found that weorðan was used in $25.91 \%$ of free translations ( $\mathrm{n}=64 / 247)$, but only $17.98 \%$ of strict translations $(n=114 / 634)$, a difference which was significant $\left(\chi^{2}(1)=6.93, p<.01\right)$. Such associations were found in Macleod (2014) to differ among texts; when the texts in this study were analysed individually, a significant association was found only for Bede $\left(\chi^{2}(1)=11.19\right.$, $p<.001)$. A possible explanation for this is that the construction with wesan, having a close parallel in Latin, could potentially have been perceived as more suitable for translating a Latin form, but that this similarity did not seem equally salient to all translators.

\section{TENSE AND TIME REFERENCE}

Our analysis also considered potential interactions between copula choice and tense. 'Tenses' in this study are verb categories which grammaticalize 'time reference' (among functional categories). The latter term refers to the temporal relationship between speech time (i.e. the time of utterance or writing or some fictitious 'now') and the situation referred to. We use the temporal categories 'past', 'future', 'present', and 'past(past)', future(past), and 'universal'. 'Past' and 'future' time correspond to situations before and after speech time, respectively. 'Present' time is one which at least overlaps with speech time, where 'overlaps' means that some part of the situation being predicated is contemporaneous with speech time. Situations which have present time reference include those denoted by performatives (such as I name this ship 'Elizabeth'), and those in which speech time is contained within the situation predicated (such as the cat is sleeping in its basket). The categories 'past(past)' and 'future(past)' are complex time references in which one time point is viewed from the point of view of another which is not speech time. Past(past) is a subset of 'past' time reference in which a more distant past situation is viewed from the perspective of a more recent past time. In future(past) a situation is anterior 
from the perspective of a future time. ${ }^{24}$ Situations with 'universal' time reference hold regardless of time, and include mathematical truths, proverbs, and logical conditionals (such as if you eat well you feel better).

Tenses grammaticalize time reference, but may grammaticalize other functional categories as well, such as aspect and modality (on modality see below). For example, the Latin claudivi is a 'perfectum' (as we call it), which grammaticalizes past time and perfective aspect, claudiebam is an 'imperfectum' which grammaticalizes past time reference and imperfective aspect, and claudiveram is a 'plusquamperfectum' which grammaticalizes past(past) time reference (and is unspecified for aspect). We use Latin terms for Latin tenses to keep them distinct from time references, since there is not always a one-for-one mapping between time reference and tense (e.g. the Latin 'praesens' can be used with future or universal time reference, and not only with present time reference). We divide the OE tense forms into two categories: 'preterite', which generally has past time reference, ${ }^{25}$ and its complement, for which we also use the Latin term 'praesens' in order to reserve the term 'present' for a semantic category. For more details on the interaction between time reference and tense in general, see Reichenbach (1947), Comrie (1985), and Klein (2009; on time reference and tense in the Latin passive, see Jones (2009: 33-47); on the OE tense system, see Mitchell (1985, I, 228-56).

\begin{tabular}{|c|c|c|}
\hline & weorðan & wesan/beon \\
\hline Preterite & $31.88 \%(n=249)$ & $68.12 \%(n=532)$ \\
\hline Praesens & $17.68 \%(\mathrm{n}=58)$ & $82.32 \%(n=270)$ \\
\hline Non-finite & $11.49 \%(n=10)$ & $88.51 \%(n=77)$ \\
\hline
\end{tabular}

Table 8: Tense and Copula

The table above shows the association of the different copulas with different tenses. Although weorðan is less frequent both in the preterite and in the praesens, as well as in non-finite constructions $^{26}$, as has previously been noted (e.g. Mitchell 1985, I, 331), weorðan occurs with significantly greater frequency in the preterite than in the praesens $\left(\chi^{2}(2)=35.24, p<.001\right)$. This

\footnotetext{
${ }^{24}$ Comrie (1985) defines such time references as 'relative', as opposed to 'absolute' time references, in which the perspective from which situation is viewed is the same as speech time.

${ }^{25} \mathrm{In} \mathrm{OE}$ it is not obligatory to mark a grammaticalized difference between past and past(past).

${ }^{26}$ All non-finite constructions here involve infinitives; no examples with participles were found.
} 
may be connected with the observed use of weorðan as a frequent structural device in narrative sequences (see Petré 2010); such narrative structures would naturally be most frequent in the preterite. The variation between praesentia and non-finite forms is not statistically significant $\left(\chi^{2}(1)=1.92, p>.05\right)$.

\section{MOOD AND MODALITY}

Another potential factor in copula choice examined in our analysis is mood, which we define as a grammaticalized expression of modality. The term 'modality' in this study refers to 'a notional category relating to whether the speaker asserts a proposition as fact'. If so, the modality is factual (or 'realis'); if not, it is non-factual (or 'irrealis'). These categories of modality are often grammaticalized in OE and Latin by the indicative and subjunctive mood, respectively.

However, this match is not always perfect, notably when the subjunctive is used 'by construction' in a purely factual sense; this is true, for example, of certain OE and Latin temporal clauses. A wide variety of approaches have been proposed to address such apparent mismatches between form and meaning, with little consensus as to the ideal solution (for review see e.g. Nordström 2010). ${ }^{27}$

\begin{tabular}{|c|c|c|}
\hline & weorðan & wesan/beon \\
\hline Indicative & $30.97 \%(n=280)$ & $69.03 \%(n=624)$ \\
\hline Imperative & $14.29 \%(\mathrm{n}=1)$ & $50.00 \%(n=6)$ \\
\hline Subjunctive (Non-fact) & $12.88 \%(n=21)$ & $87.12 \%(n=142)$ \\
\hline Subjunctive (Other) & $19.05 \%(n=4)$ & $80.95 \%(n=17)$ \\
\hline
\end{tabular}

Table 9: Mood and Copula

This table shows the associations of the copulas with different moods. Some of the passive constructions in the data were potentially ambiguous in their morphology and semantics between indicative and subjunctive readings, generally in the preterite plural (see Mitchell 1985: I, 252-6); these have been excluded from the figures above. In the analysis two types of subjunctive are distinguished, those in which the subjunctive mood has significant semantic content denoting the non-factuality of the situation, and those in which its use is occasioned

\footnotetext{
${ }^{27}$ For a discussion of the relationship between modality and mood, see Palmer (2001). On the interaction between modality and aspect, see Abraham and Leiss (2008: 3-41). For further discussion of modality in relation to the passive (with references), see Jones (2009: 27-9).
} 
primarily by a particular syntactic construction and it makes little semantic contribution to the sentence. The two types can be seen in the following examples, respectively:

$\begin{array}{lllll}\text { God us } & \text { drencte [...] mid tearum, } & \\ \text { God us } & \text { drenched with tears, } & & \\ \text { swa ðxtte aghwelces } & \text { mannes } \bmod [\ldots] \text { ware } & \text { geðwaned } \\ \text { so that each } & \text { man's mood were.SUBJ moistened }\end{array}$

'God drenched us with tears, so that each man's spirit would be softened.'

(CP 53.413.10)

(23) ear pan pe he bebyrged ware. eall folc geceas Eadward to cynge ere that that he buried were.SUBJ all folkchose Edward to king 'Before he was buried, all the people chose Edward as king.'

(ChronE 1041.4)

In the first example, the preterite subjunctive is used to denote a purpose, a purpose that is contingent upon the original action and may not necessarily be realised in every case. In the second example the preterite subjunctive is used because of the temporal clause with $a r$ 'before' (see Mitchell 1985: II, 373-87); there is no suggestion that the burial did not occur or might not have occurred. The semantic difference between the two subjunctives can be seen in part through their Modern English translations; the first requires a modal expression, while the second can be rendered with a bare indicative. The non-factual subjunctives show a significant association with wesan $\left(\chi^{2}(3)=26.47, p<.001\right)$; when these are removed from the sample, there are no further significant associations between copula choice and $\operatorname{mood}\left(\chi^{2}(2)=2.29, p>.05\right)$. This may be related to the possibility raised in connection with subjunctive ingressives above: since the situations denoted by subjunctive clauses are less likely to be interpreted as simultaneous with that of another verb, there is less need for disambiguation through the use of a copula with a more restricted Aktionsart. Where there is little possibility of such ambiguity, transitional and non-transitional expressions can be seen as 'functionally equivalent' (Jones 2009: 29-30) 
The overall variation among different texts in their choice of copula can be seen in the table below.

\begin{tabular}{|r|l|l|}
\cline { 2 - 3 } \multicolumn{1}{c|}{} & \multicolumn{1}{c|}{ weorðan } & \multicolumn{1}{c|}{ wesan/beon } \\
\hline Bede & $4.92 \%(\mathrm{n}=9)$ & $95.08 \%(\mathrm{n}=174)$ \\
\hline$C P$ & $28.57 \%(\mathrm{n}=36)$ & $71.43 \%(\mathrm{n}=90)$ \\
\hline Or & $43.90 \%(\mathrm{n}=36)$ & $56.10 \%(\mathrm{n}=46)$ \\
\hline$G D(\mathrm{C})$ & $14.56 \%(\mathrm{n}=23)$ & $85.44 \%(\mathrm{n}=135)$ \\
\hline$G D(\mathrm{H})$ & $33.33 \%(\mathrm{n}=46)$ & $66.67 \%(\mathrm{n}=92)$ \\
\hline OT & $38.03 \%(\mathrm{n}=27)$ & $61.97 \%(\mathrm{n}=44)$ \\
\hline BenR & $0.81 \%(\mathrm{n}=1)$ & $99.19 \%(\mathrm{n}=122)$ \\
\hline WHom & $51.26 \%(\mathrm{n}=61)$ & $48.74 \%(\mathrm{n}=58)$ \\
\hline ChronE & $40.31 \%(\mathrm{n}=79)$ & $59.69 \%(\mathrm{n}=117)$ \\
\hline
\end{tabular}

Table 10: Analysis by Text

It can be seen that the texts vary to a degree that has obvious statistical significance $\left(\chi^{2}(8)=174.44, p<.001\right)$. The infrequency of weorðan in Bede has long been noted (see Kilpiö 1989:98-101); the text of Bede has a number of Mercian dialect features, and it has been suggested that the avoidance of weorðan may also be a Mercian feature, although the scarcity of unambiguously Mercian data makes it difficult to test this hypothesis. The infrequency of weorðan in BenR may also seem particularly striking. However, in this text a majority of the examples are praesens subjunctives, for which weorðan is generally less common (see above under 'Tense and mood'), and it is therefore necessary to correct for any resulting bias. The table below shows the data for indicatives only:

\begin{tabular}{|r|l|l|}
\cline { 2 - 3 } \multicolumn{1}{c|}{} & \multicolumn{1}{c|}{ weorðan } & wesan/beon \\
\hline Bede & $4.14 \%(\mathrm{n}=6)$ & $95.86 \%(\mathrm{n}=139)$ \\
\hline$C P$ & $29.67 \%(\mathrm{n}=27)$ & $70.33 \%(\mathrm{n}=64)$ \\
\hline Or & $47.14 \%(\mathrm{n}=33)$ & $52.86 \%(\mathrm{n}=37)$ \\
\hline$G D(\mathrm{C})$ & $19.01 \%(\mathrm{n}=23)$ & $80.99 \%(\mathrm{n}=98)$ \\
\hline$G D(\mathrm{H})$ & $37.84 \%(\mathrm{n}=42)$ & $62.16 \%(\mathrm{n}=69)$ \\
\hline$O T$ & $47.17 \%(\mathrm{n}=25)$ & $52.83 \%(\mathrm{n}=28)$ \\
\hline BenR & $2.78 \%(\mathrm{n}=1)$ & $97.22 \%(\mathrm{n}=36)$ \\
\hline WHom & $51.11 \%(\mathrm{n}=46)$ & $48.89 \%(\mathrm{n}=44)$ \\
\hline ChronE & $41.71 \%(\mathrm{n}=78)$ & $58.29 \%(\mathrm{n}=109)$ \\
\hline
\end{tabular}

Table 11: Analysis by Text (Indicatives only)

It can be seen that, even when indicatives alone are considered, weorðan remains infrequent in $B e n R$, albeit to a lesser degree; an explanation for this may lie in the tripartite distinction in the praesens between weorðan, wesan, and beon, which will be examined below. Another significant change is the increase in the use of weordan in the revision of $G D\left(\chi^{2}(1)=10.18\right.$, 
$p<.01$ ); a number of passive constructions that originally used wesan in MS C were rephrased to use weorðan instead in MS H. The possibility has been raised that this represents a diachronic change away from wesan and towards weorðan for eventive passives (for discussion see Yerkes 1982). However, given the presence of early texts such as $O r$ that use weorðan more frequently, and the presence of later texts such as BenR that avoid it, the issue may not be one of straightforward diachronic change; it is important to consider whether the observed variation might instead reflect diachronically stable stylistic preferences (cf. Macleod 2014: 337-9).

\subsection{BEON AND WESAN}

\section{PREVIOUS LITERATURE}

At this point we revisit the distinction between wesan and beon. It is generally true that beon contrasts with wesan in its greater use in iterative, habitual, and generic contexts, and its use with future time reference (Kilpiö 1993). It should be noted, however, that these tendencies are not absolute and that there are varying degrees of overlap between wesan and beon in these contexts, a finding which is not unexpected given the ability of pragmatic context to create readings that do not reflect the basic Aktionsart of a verb. It should also be observed that beon does not seem to share the inherent transitionality of weorðan; beon is found even in non-transitional, stative passives, such as the following (cited by Kilpiö 1989: 58):

\begin{tabular}{|c|c|c|c|}
\hline Ne bið se no & $\begin{array}{l}\text { gefyllec } \\
\text { filled }\end{array}$ & $\begin{array}{c}d \text { ठаes Halg } \\
\text { the Holy }\end{array}$ & Ghost's \\
\hline$f$ & ðone & $m$ & $\begin{array}{l}\text { ryhtwislices } \\
\text { righteous }\end{array}$ \\
\hline
\end{tabular}

'He is not filled with the Holy Ghost who abandons the fervour of righteous zeal.' (CP 40.291.9)

This example shows the stative use of beon (here in a generic, gnomic context). In telic contexts, however, it has been suggested that passives with weorðan resemble passives with beon in sharing beon's aforementioned Aktionsart properties (Kilpiö 1989: 61-7). Like beon, passives with weorðan often have future reference; while this may be related to its original meaning 'become' (e.g. Kilpiö 1989: 61), it can also be seen as a manifestation of the ordinary OE use of 
the praesens to refer to future time (Petré 2014: 186-9). The latter interpretation might suggest that wesan is the unusual copula, in that its Aktionsart predisposes it to be seen as referring to incomplete, in-progress situations to a degree that makes it generally unsuitable for future use. Given the similarity in Aktionsart of beon and weorðan, a closer examination of their distribution has the potential to shed additional light on the factors influencing copula choice.

\section{THE COMPOSITIONAL MODEL}

In analysing the variation among beon, wesan, and weorðan, we have used only data from the praesens indicative. Beon lacks a preterite, and therefore cannot alternate with other copulas in this tense, while in the subjunctive and non-finite forms a single variant, either from beon or wesan, is generally preferred in each category, although the choice of form is subject to variation among dialects and texts (see Kilpiö 1993: 96-7).

\begin{tabular}{|c|c|c|c|}
\hline & weorðan & wesan & beon \\
\hline $\mathrm{NT}^{\mathrm{NT}}$ & $0.00 \%(n=0)$ & $76.52 \%(\mathrm{n}=101)$ & $23.48 \%(\mathrm{n}=31)$ \\
\hline $\mathrm{T}^{\mathrm{NT}}$ & - & - & - \\
\hline $\mathrm{NT}^{\mathrm{T}}$ & $0.00 \%(\mathrm{n}=0)$ & $86.11 \%(n=93)$ & $13.89 \%(n=15)$ \\
\hline $\mathrm{T}^{\mathrm{T}}$ & $26.13 \%(n=52)$ & $12.06 \%(n=24)$ & $61.81 \%(n=123)$ \\
\hline
\end{tabular}

Table 12: Actual Distributions of Copulas

The data in this table are drawn from the same dataset as Table 4 above, broken down further to differentiate between wesan and beon. The few ingressive examples identified in this study were either preterite indicative or praesens subjunctive, and therefore do not appear; none of those in the praesens subjunctive involved beon. As can be seen, beon is used more frequently than wesan in transitional constructions, to a highly significant degree $\left(\chi^{2}(2)=156.43, p<.001\right)^{28}$; this is compatible with previous observations regarding the Aktionsart of beon, as discussed above. However, beon is also used in stative constructions; this supports the prediction of the compositional model that beon is not inherently transitional in its semantics and that despite their differences in Aktionsart it patterns with wesan in this respect. If beon resembled weorðan in having an Aktionsart well suited to transitional constructions but differed from it in also being

\footnotetext{
${ }^{28}$ This significance was calculated using only the data for wesan and beon; weorðan was excluded to avoid measuring the significance of the difference between weorðan and the other two copulas.
} 
compatible with stative constructions, this raises the possibility of competition between these copulas, a possibility that will be examined in greater detail below.

\section{SEMANTIC CLASSIFICATION OF THE PRAESENS}

In our analysis we distinguish three semantic types of praesens: the specific praesens, referring to unique situations obtaining at the actual moment of speech; the generic praesens, referring to recurrent, habitual, or universal situations; and futures. Constructions for which there is substantial ambiguity among these readings have been excluded. The three types of praesens can be seen in the following examples, respectively:

$n u$ is se tima pat ðeos woruld is gemancged mid manigfealdan mane now is the time that this world is mixed with manifold evils 'Now is the time when this world is disturbed with numerous crimes.'

(WHom V.23)

ðณt geðreatade mod bið suiðe raðe gehwierfed to fiounga

the threatened mood is strongly quickly turned to hating

'The rebuked spirit is very soon turned to hatred.'

(CP 21.167.13)

(27) ðonne ða heortan ðe hie ahebbað [...] weorðað ofdune aworpne then the hearts that they exalt become down cast 'Then [on Doomsday] the hearts that they exalt will be cast down.' (CP 35.245.24)

As discussed above, the broad distribution of beon and wesan is generally agreed, and is confirmed by the data below. However, less attention has been given to variation among texts; the most comprehensive study (Kilpiö 1989) examines only two, Bede and CP. The table below shows the distribution of the three copulas among the different praesens types, with the different texts shown separately. The only praesens indicatives in our sample of $O r$ are statives and were therefore excluded.

\begin{tabular}{|r|c|c|c|c|}
\cline { 2 - 4 } \multicolumn{2}{l|}{} & weorðan & wesan & beon \\
\hline Bede & Specific & - & $50.00 \%(\mathrm{n}=1)$ & $50.00 \%(\mathrm{n}=1)$ \\
\hline
\end{tabular}




\begin{tabular}{|c|c|c|c|c|}
\hline & Generic & - & - & $100.00 \%(\mathrm{n}=2)$ \\
\hline & Future & - & - & $100.00 \%(\mathrm{n}=2)$ \\
\hline \multirow{3}{*}{$C P$} & Specific & - & $100.00 \%(\mathrm{n}=1)$ & - \\
\hline & Generic & $29.63 \%(\mathrm{n}=16)$ & - & $70.37 \%(\mathrm{n}=38)$ \\
\hline & Future & $80.00 \%(n=4)$ & - & $20.00 \%(n=1)$ \\
\hline \multirow{3}{*}{$G D(\mathrm{C})$} & Specific & - & $100.00 \%(\mathrm{n}=3)$ & - \\
\hline & Generic & - & - & $100.00 \%(n=7)$ \\
\hline & Future & - & - & $100.00 \%(\mathrm{n}=1)$ \\
\hline \multirow{3}{*}{$G D(\mathrm{H})$} & Specific & - & $100.00 \%(n=3)$ & - \\
\hline & Generic & - & - & $100.00 \%(n=7)$ \\
\hline & Future & - & - & $100.00 \%(\mathrm{n}=1)$ \\
\hline \multirow{3}{*}{$O T$} & Specific & - & - & $100.00 \%(\mathrm{n}=1)$ \\
\hline & Generic & - & - & - \\
\hline & Future & - & - & $100.00 \%(n=4)$ \\
\hline \multirow{3}{*}{ BenR } & Specific & - & $100.00 \%(\mathrm{n}=1)$ & - \\
\hline & Generic & - & - & $100.00 \%(\mathrm{n}=12)$ \\
\hline & Future & - & - & $100.00 \%(n=8)$ \\
\hline \multirow{3}{*}{ WHom } & Specific & - & $100.00 \%(n=2)$ & - \\
\hline & Generic & $48.00 \%(\mathrm{n}=12)$ & $12.00 \%(n=3)$ & $40.00 \%(n=10)$ \\
\hline & Future & $56.52 \%(\mathrm{n}=13)$ & - & $43.48 \%(n=10)$ \\
\hline \multirow{3}{*}{ ChronE } & Specific & - & - & - \\
\hline & Generic & - & - & $100.00 \%(n=1)$ \\
\hline & Future & - & - & - \\
\hline \multirow{3}{*}{ Total: } & Specific & & $84.62 \%(n=11)$ & $15.38 \%(n=2)$ \\
\hline & Generic & $25.92 \%(n=28)$ & $2.78 \%(\mathrm{n}=3)$ & $71.30 \%(n=77)$ \\
\hline & Future & $38.64 \%(n=17)$ & & $61.36 \%(n=27)$ \\
\hline
\end{tabular}

Table 13: Beon and other copulas in transitional praesens constructions

It can be seen from this table that considerable variation exists among texts in their preferred copula for generic and future constructions. In some texts, such as BenR, the scarcity of weorðan can be related to the fact that most passives are in the praesens and to a preference for beon over weorðan in the contexts in which the latter might be used. In other texts, such as $O T$, beon is still preferred for generics and futures, but the frequent occurrence of weorðan in narrative past contexts makes its use proportionally quite frequent in general. Other texts, such as $C P$ and WHom, make free use of both beon and weorðan for such purposes; it has been suggested that this variation may have been exploited for stylistic purposes (Kilpiö 1989) or to draw finer distinctions of transitionality (Petré 2014). In instances where the choice of copula is not constrained by the Aktionsart of the copula or the participle, a wide range of factors would seem to be involved in producing the observed variation. We also analysed the variation between wesan and beon in stative contexts, for purposes of comparison. This revealed the same 
general tendencies as in transitional constructions, with wesan preferred $(100.0 \%, \mathrm{n}=150)$ for specific presents and beon for generics $(85.1 \%, \mathrm{n}=47)$; future statives in this sample were rare, with a single example using beon being found.

The question may also be asked whether any significant differences between wesan and beon were revealed by the same tests previously applied to weorðan and wesan/beon. In the following discussion, although the data are again restricted to the praesens indicative, both transitional and non-transitional constructions are included, since both types occur with each of these copulas.

\begin{tabular}{|c|c|c|}
\hline & wesan & beon \\
\hline Perfective & $54.22 \%(\mathrm{n}=90)$ & $45.78 \%(n=76)$ \\
\hline Imperfective (Continuous) & $52.27 \%(\mathrm{n}=115)$ & $47.71 \%(n=105)$ \\
\hline Imperfective (Iterative) & $23.33 \%(\mathrm{n}=7)$ & $76.67 \%(n=23)$ \\
\hline
\end{tabular}

Table 14: Translation and Aspect (wesan/beon)

It is perhaps interesting, given the foregoing discussion of the Aktionsart of beon, that no preference was found for it as a translation of Latin perfective constructions; however, Latin perfective passives can have either eventive or stative meaning, and many of the stative examples may have been felt to be more compatible semantically with wesan. A significant preference does emerge for the use of beon in iterative contexts $\left(\chi^{2}(2)=10.02, p<.01\right)$; this phenomenon, which has long been noted, has been related to the habitual meaning of iterative constructions (e.g. Kilpiö 1989: 59-60). No significant difference was found between wesan and beon in their use in strict vs. free translations, or in their use with or without overt agents. It was found that $60.68 \%$ of constructions with inflected participles used beon ( $\mathrm{n}=68 / 112)$, as opposed to only $44.73 \%$ of constructions with uninflected participles $(n=136 / 304)$, a significant degree of variation $\left(\chi^{2}(1)=8.36, p<.01\right)$. However, the presence or absence of participial inflection in Old English was affected by many different factors (e.g. Mitchell 1985: I, 16-20); the task of isolating the difference between these copulas from other potential variables is beyond the scope of the present work.

\section{SUMMARY OF RESULTS AND DISCUSSION}

In this section we discuss the significance of our results and the ways in which they help answer the questions set out in section 2.3. 
We find strong evidence that the distribution of the combinations weorðan or wesan/beon + passive participle can be explained compositionally in terms of transitional and nontransitional Aktionsart categories; this suggests that such combinations are ungrammaticalized constructions. Our corpus shows considerable variation in its choice of copula from one text to another in other respects (see section 5.3 'Variation among texts'), but in all texts the choice of copula conforms almost exactly to our compositional model.

When the Aktionsart of the whole passive construction is transitional, our model allows both copula to be used, but does not require this. Since the combination of weorðan + passive participle guarantees a transitional reading, while that of wesan/beon does not (because it also allows a non-transitional reading), we might expect a division of function to emerge, whereby wesan/beon would be used to form only non-transitional constructions. This would not, under our definition, be an example of grammaticalization, because the meaning of the combination of wesan/beon + passive participle would still be compositional. Rather, it would be an example of constructionalization, according to which, even though this combination could be interpreted compositionally to denote transitional or non-transitional Aktionsart, speakers would know that it would be used only for the latter (see section 2.2). However, we do not find evidence of such a division of function between the copulas: indeed, wesan/beon occurs more often than weorðan even in transitional constructions, just as in other types.

However, when the passive construction is transitional and both copulas are used, we do find significant patterns of distribution along dimensions other than Aktionsart. It is noteworthy that, in each case, it is wesan/beon which is preferred. First, wesan/beon is preferred to weorðan when the aspect is iterative, perhaps because wesan/beon allows the iterated event to be viewed in its entirety as non-transitional, whereas weorðan would make the construction markedly transitional. Second, in some texts there is a preference for wesan/beon in strict translations from Latin, i.e. those in which the OE passive translates a Latin passive, as opposed to free translations, in which the OE passive translates some other type of construction. This may reflect the fact that wesan/beon, as the verb 'to be', corresponds to the verb 'to be' used in Latin periphrastic passives. Third, wesan/beon is preferred for non-factual subjunctives. We suggest that this is because, in these contexts, it is often unimportant to distinguish between a transition into a state and the state itself. 
We find further patterns of distribution when we analyse wesan and beon separately rather than as a single verb. Beon is preferred significantly over both weorðan and wesan when the Aktionsart is transitional, but beon is, like wesan, still used for non-transitional Aktionsart, so its functional range does not correspond exactly to that of weorðan. However, when we separate the instances of the praesens into three different temporal categories of specific present (i.e. continuing at speech time), generic, and future, our results show a clear pattern: wesan is preferred for specific presents and beon is preferred (over both wesan and weorðan) for generics and futures.

Our findings may shed light on the reasons why weorðan was lost after the OE period. If, as we argue, the combination of weorðan and a passive participle was not grammaticalized or constructionalized, the loss of weorðan would lead to the loss only of a lexeme rather than to the loss of a construction. Moreover, the combination between wesan/beon and the passive participle can be used to express three of the four Aktionsart categories in our semantic model, so that, even without weorðan, the language still had the resources to denote situations in these categories. The exception is the ingressive Aktionsart category. However, as we have seen (section 5.1), this is a very rare category which in any case could be expressed after the loss of weorðan by another verb meaning 'become' with the passive participle. ${ }^{29}$ When we analyse the choice of copula to denote transitional situations, i.e. those in which weorðan and wesan/beon are interchangeable according to our model, we find that wesan/beon is actually preferred. This might seem surprising, because in combination with the passive participle of a transitional verb, weorðan guarantees a transitional reading, whereas wesan/beon also allows a non-transitional (i.e. resultative) reading. A possible clue to the preference for wesan/beon may lie in the respective functions of wesan and beon in the praesens. Here we find that beon is used to denote transitional situations considerably more often than weorðan. However, the strongest pattern in the distribution between wesan, beon, and weorðan in the praesens is based on time reference, not Aktionsart, with wesan preferred for specific presents and beon for generics and futures. It is possible that, in the praesens, these temporal distinctions were more salient than distinctions based on Aktionsart, and that the need to mark transitional Aktionsart unambiguously with weorðan was secondary. This in turn could have led to weorðan being a marginal verb in passive

\footnotetext{
${ }^{29}$ Petré provides an analysis of weorðan's successors in eME, and finds that the combination of weaxan + passive participle is used to express ingressive situations (2014: 197-225).
} 
constructions altogether. The fact that weorðan is used less than wesan even with past time reference, where there are not the competing temporal (specific/generic/future) distinctions of the praesens, is consistent with a situation in which weorðan had a marginal status in passive constructions.

Although the passive construction with weorðan was a marginal one in $\mathrm{OE}$, it does not, to judge by our corpus, become more so during the OE period: the preference for wesan/beon over weorðan to denote transitional situations is as much a feature of the early as the late texts. This suggests that passive constructions played an enabling rather than a leading part in the disappearance of weorðan from English: the lack of grammaticalization in the passive meant that the loss of this lexeme (along with its replacement by others, notably becuman and weaxan) could occur without great disruption to the capacity of the language to denote passive situations. This would be compatible with an account in which the trigger for the loss of weorðan came, not from the passive, but from elsewhere, for example from the blurring of the early OE semantic distinction between weorðan 'become' and geweorðan 'happen' (see ftn 11), or from the shift the language from 'bounded' to 'unbounded' sentences (see Petré 2010).

It may be interesting to contrast our findings for OE with the situation in Old High German (OHG). In terms of our model, the distribution of werdan or wesan with a passive participle in early OHG texts is very similar to what we have found for weorðan and wesan/beon in OE. However, there is evidence that, in late $\mathrm{OHG}$, the combination of copula and passive participle had already developed some way towards the pattern we see in modern German. First, the construction with werdan appears to have become grammaticalized, so that it was used for eventive situations in general, and not only for transitional ones (for details, see Jones 2009). Second, there is evidence that the choice of copula became constructionalized, so that wesan became used only for non-transitional situations. Moreover, OHG did not have alternative variants of the verb 'to be' corresponding to those of wesan/beon in OE: although the OHG verb is suppletive, in general only one variant is available for each part of the paradigm. The contrast between English and German can thus be summarized as follows. In English the combination of weorðan or wesan/beon + passive participle was not grammaticalized, nor did a clear opposition develop between the two through constructionalization; moreover, beon, one of the forms of the verb 'to be', to some extent competed with weorðan; subsequently weorðan was lost. In German the combination of werdan or wesan + passive participle was grammaticalized and 
constructionalized; moreover, there was no system of alternative forms of the verb 'to be' to compete with werdan; and werdan survived in the language. The contrast suggests a situation in which the lack of grammaticalization in the OE passive, along with the division of function between wesan and beon, meant that weorðan could be dispensed with at relatively little cost.

If the OE passive could express the same semantic range as the present-day English passive without being grammaticalized, it may be asked whether grammaticalization of the passive has taken place at any point in the history of English. We would suggest that the passive construction of 'to be' + passive participle does, in fact, show signs of grammaticalization since the OE period. Such a development can be seen in the appearance of indirect passives (e.g. John was given a book). Such passives are no longer fully compositional: the passive participle on its own cannot express benefactive meaning (e.g. John was given $\neq$ 'John received'), and therefore the copula in an indirect passive is not simply expressing a subject-predicate relationship. Nor do indirect passives have a stative meaning; John is given a book cannot be used in a resultative sense to mean that John now possesses a book, unlike similar constructions in which the subject corresponds to the direct object of an active verb (e.g. John is endowed with many virtues). (Denison 1993: 422 places a different interpretation on indirect passives as a sign of grammaticalization, viewing them as an indicator of increasingly transparent argument structure rather than of decreasing semantic compositionality.) Indirect passives are first reliably attested in Middle English (see e.g. Denison 1993: 110-112). However, the reanalysis necessary for their appearance may have taken place at an earlier date, which could be difficult to fix exactly given the paucity of evidence from the period immediately preceding this development.

\section{CONCLUSION}

We address two main questions relating to the OE passive which have been raised in previous studies:

1. Are passive constructions grammaticalized or constructionalized?

2. On what basis are the copulas distributed in passive constructions?

There has previously been a lack of consensus both on the grammatical status of OE passives and on the criteria that could be used to assess this. Our starting point is a compositional model for the interaction between copula and passive participle which is based on Aktionsart. This model 
predicts that transitional passive situations will be expressed using either weorðan or wesan/beon + passive participle, and that non-transitional situations will be expressed only with wesan/beon + passive participle. Using a selected corpus of OE prose texts, translated and not, we find a distribution of the copulas almost exactly in line with this model for all authors and throughout the period. To this extent we conclude that the combination of copula and passive participle is not grammaticalized in OE. When the Aktionsart of the combination is transitional, our model allows both copulas to be used, but does not require this. Since the use of weorðan in such constructions would guarantee a transitional reading, we might expect a division of function to emerge between the copulas, such that wesan/beon would be used only for non-transitional situations. This would parallel the distribution which emerged between the cognate copula verbs werdan and wesan during the Old High German period, and would be an example of what we term 'constructionalization', a process whereby the choice of construction, which in this case amounts to the choice of copula, would invite only one of two compositionally possible readings. However, we do not find this in $\mathrm{OE}$, as both copulas are used for transitional situations. In common with previous studies, we find that wesan/beon is the preferred copula in such cases, even though the choice of weorðan would be less ambiguous. Our main explanation for this is that, in the praesens, wesan/beon offers alternative forms (either wesan-based or beon-based), which allow temporal distinctions to be signalled, and that these distinctions were felt to be more salient than Aktionsart distinctions. However, according to our analysis, there is no need to assume that the unequal distribution of the two copulas is related to grammaticalization. Our semantic model provides a clearer set of criteria than was previously available for assessing the grammaticalization of $\mathrm{OE}$ passives; the conclusions drawn from it, although negative, may rest on a firmer foundation than previous assessments of the status of these constructions.

The lack of grammaticalization of weorðan and its marginal status in the OE passive minimized the functional loss to the language when weorðan eventually disappeared. However, given that weorðan's marginal status in the passive does not become any more pronounced during the period, it is possible that, while the marginal position of weorðan in the passive facilitated its eventual loss to the language, it did not trigger it, and that the decisive push came from elsewhere. Possible candidates are the blurring of the semantic distinction between 
weorðan 'become' and geweorðan 'happen' during the OE period and, as proposed by Petré (2010), the shift in the language from 'bounded' to 'unbounded' sentences. ${ }^{30}$

Our study suggests two main avenues for further research. The distribution between weorðan and wesan/beon in $\mathrm{OE}$ passive constructions is also found between their cognates meaning 'become' and 'to' in other early Germanic languages, notably Gothic, Old Norse, and Old High German. However, the various Germanic languages have moved apart from what appears to be a common starting-point. We have highlighted differences between OE and Old High German that correlate with the different paths taken by passive constructions in those languages. However, detailed work is needed to examine whether the correlation is more than coincidental. The second possible path for future research relates particularly to the fate of OE weorðan. If, as we propose, the marginal status of this copula in passive constructions played an enabling, rather than a concluding part in its eventual loss, the implication is that the impetus for this development is to be found in an analysis of the distribution and function of weorðan outside of passive constructions. While it has been suggested that passives with weorðan were semantically or pragmatically marked in some way (e.g. Kilpiö 1989; Petré 2014), the precise connotations of these constructions have proved resistant to explicit codification. Despite the valuable data provided by studies such as Petré (2014) on the distribution of weorðan, there is room for more work on the precise collocations in which this copula occurred outside the passive in Old and Middle English.

\footnotetext{
${ }^{30}$ For other theories for the loss of weorðan, see Petré (2014).
} 


\section{TEXTUAL SOURCES}

Bosworth, Joseph, and T. NorthCote Toller (eds.) 1898. An Anglo-Saxon Dictionary. Oxford: Clarendon.

Clement VIII, PoPe (ed.) 1938. Biblia Sacra: Juxta Vulgatam Clementinam. Rome: Desclée.

DE VogüE, AdAlbert (ed.) 1979. Dialogues: Grégoire le Grand. Vol. 2. (Sources Chrétiennes, 260.) Paris: Cerf.

Judic, Bruno, and Floribert Rommel (eds.) 1992. Règle pastorale. (Sources Chrétiennes, 381-2.) Paris: Cerf.

Plummer, Charles (ed.) 1896. Venerabilis Baedae historiam ecclesiasticam gentis Anglorum. Oxford: Clarendon. Online:

http://www.perseus.tufts.edu/hopper/text?doc=Perseus\%3atext\%3a1999.02.0135.

SCHMitz, PhiliBert (ed.) 2009. Règle de Saint Benoît. 6th edn. Turnhout: Brepols.

SweEt, HenRy (ed.) 1883. King Alfred's Orosius. (Early English Text Society, 79.) London: Trübner.

TAYLOR, ANN; ANTHONY WARnER; SUSAN PintzuK; and Frank Beths (eds.) 2003. The YorkToronto-Helsinki parsed corpus of Old English prose. York: University of York, electronic.

\section{REFERENCES}

ABraham, Werner. 1991. 'Aktionsartsemantik und Auxiliarisierung im Deutschen' in Neue Fragen der Linguistik. Akten des 25. Linguistischen Kolloquiums, Paderborn 1990. Vol 1: Bestand und Entwicklung, ed. by Elisabeth Feldbusch et al. Tübingen: Niemeyer (Linguistische Arbeiten, 270), 125-133.

ABRAHAM, WeRnER, and ElisABETH LeISS (eds). 2008. Modality-Aspect Interfaces. Amsterdam: John Benjamins.

BAMMESBERGER, ANNELIESE. 1979. 'Die Deutung partiell konkurrierender Formen:

Überlegungen zum gotischen was-, warb-Passiv' in Befund und Deutung: Zum Verhältnis von Empirie und Interpretation in Sprach- und Literaturwissenschaft. Hans Fromm zum 26. Mai 1979 von seinen Schülern, ed. by Klaus Grubmüller et al. Tübingen: Niemeyer, 96-110.

Barnes, Michael. ${ }^{32} 2008$. A New Introduction to Old Norse. Part I: Grammar. London: Viking Society for Northern Research. 
BAtely, JANET (ed.) 1980. The Old English Orosius. (Early English Text Society SS, 6.) London: Oxford University Press.

Behaghel, Отtо. 1923-1932. Deutsche Syntax: Eine geschichtliche Darstellung. 4 vols. Volume II ('Die Wortklassen und Wortformen' (1924)), repr. 1989. Heidelberg: Winter.

Bergs, AleXANDer and Gabriele Diewald (eds). 2008. Constructions and language change. Berlin : de Gruyter

BethuRum, DoRothy (ed.) 1957. The homilies of Wulfstan. Oxford: Clarendon.

CAMPBELL, LYLE. 2001. 'What's wrong with grammaticalization?', Language Sciences 23, 113161.

Clemoes, Peter. 1966. The composition of the Old English text. The Old English illustrated Hexateuch, ed. by C. R. Dodwell \& Peter Clemoes, 42-53. Copenhagen: Rosenkilde \& Bagger.

Comrie, Bernard. 1976. Aspect: An Introduction to the Study of Verbal Aspect and Related Problems. Cambridge: Cambridge University Press.

ComRIE, Bernard. 1985. Tense. Cambridge: Cambridge University Press.

DENISON, DAVID. 1993. English historical syntax: Verbal constructions. London: Longman.

DowTy, DAVID RoACH. 1972. Studies in the Logic of Verb Aspect and Time Reference in English. Diss. Austin, Texas (Microfiche, Ann Arbor, Mich.: Xerox University Microfilms, 1973).

DOWTY, DAVID RoACH. 1977. 'Toward a Semantic Analysis of Verb Aspect and the English "Imperfective" Progressive', Linguistics and Philosophy 1, 45-77.

EROMS, HANS-WERNER. 1990. 'Zur Entwicklung der Passivperiphrasen im Deutschen' in Neuere Forschungen zur historischen Syntax des Deutschen, ed. by A. Betten. Tübingen: Niemeyer.

FAARLund, JAN TeRJe. 2004. The Syntax of Old Norse. Oxford: Oxford University Press.

FEAR, A. T. (trans.) 2010. Orosius: Seven books of history against the pagans. Liverpool: Liverpool University Press.

GRETsCh, MechthILD. 1992. The Benedictine Rule in Old English: A document of Bishop Æthelwold's reform politics. Words, texts and manuscripts: Studies in Anglo-Saxon culture presented to Helmut Gneuss on the occasion of his sixty-fifth birthday, ed. by Michael Korhammer, Karl Reichl, and Hans Sauer, 131-58. Cambridge: Brewer.

HEINE, BERND. 2003. 'Grammaticalization' in Janda \& Joseph (eds.) 2003. The handbook of historical linguistics. Oxford: Blackwell, 575-601. 
IRVINE, SuSAN (ed.) 2004. MS E. (The Anglo-Saxon Chronicle: A Collaborative Edition, 7.) Cambridge: Brewer.

JONES, HowARD. 2009. Aktionsart in the Old High German passive. Hamburg: Buske.

KILPIÖ, MATTI. 1989. Passive constructions in Old English translations from Latin: With special reference to the OE Bede and the Pastoral Care. Helsinki: Societé Néophilologique.

KILPIÖ, MATTI. 1993. Syntactic and semantic properties of the present indicative forms of the verb to be in Old English. Early English in the Computer Age: Explorations through the Helsinki Corpus, ed. by Matti Rissanen, Merja Kytö \& Minna Palander-Collin, 97-116. Berlin: de Gruyter.

Klein, WolfGang. 2009. 'How time is encoded' in The Expression of Time, ed. by Wolfgang Klein and Ping Li. Berlin: de Gruyter.

LehMann, Christian. 1995. Thoughts on Grammaticalization. Munich: Lincom.

LEISS, ELISABETH. 1992. Die Verbalkategorien des Deutschen: Ein Beitrag zur Theorie der sprachlichen Kategorisierung. Berlin: de Gruyter.

LiGHTFOOT, DAVID. 1979. Rule classes and syntactic change. Linguistic Inquiry 10.83-108.

LuSSKy, GEORGE. 1924. "uuerdan” und "uuesan” mit dem Partizip Passiv im ahd. Tatian', Journal of English and Germanic Philology 23, 342-69.

MACLEOD, MORGAN. 2014. Synchronic variation in the Old English perfect. Transactions of the Philological Society 112.319-43.

MAILHAMmER, ROBERT, and ElENA SMIRNOVA. Incipient grammaticalization: Sources of passive constructions in Old High German and Old English. Comparative studies in early Germanic languages: With a focus on verbal categories, ed. by Gabriele Diewald, Leena Kahlas-Tarkka, and Ilse Wischer, 41-69. Amsterdam: Benjamins.

Marsden, Richard. 1995. The text of the Old Testament in Anglo-Saxon England. Cambridge: Cambridge University Press.

McFadden, Thomas, and Artemis Alexiadou. 2010. Perfects, resultatives and auxiliaries in Earlier English. Linguistic Inquiry 41, 389-425.

Mitchell, Bruce; Christopher BALl; and Angus CAMEron. 1975. Short titles of Old English texts. Anglo-Saxon England 4.201-21.

MitChell, BruCE. 1985. Old English Syntax. 2 vols. Oxford: Oxford University Press.

Mustanoja, Tauno F. 1960. A Middle English Syntax. Helsinki: Societé Néophilologique.

NEDJALKOV, VladimiR. 2001. 'Resultative constructions', in M. Haspelmath (ed.), 
Language typology and universals. An international handbook, vol. 2. Berlin: de Gruyter, pages 928-940.

Nedjalkov, Vladimir and Sergej JaXontov. 1988. 'The Typology of Resultative Constructions' in Typology of Resultative Constructions, ed. by Vladimir P. Nedjalkov, Eng. trans. ed. by Bernard Comrie. Amsterdam: Benjamins (Typological Studies in Language, 12), 3-62.

NORDSTRÖM, JACKIE. 2010. Modality and Subordinators. Amsterdam: Benjamins.

OUBOUZAR, ERIKA. 1974. 'Über die Ausbildung der zusammengesetzten Verbformen im deutschen Verbalsystem', Beiträge zur Geschichte der deutschen Sprache und Literatur 95, 5-96, Halle.

PALMER, FrAnK. 2001. Mood and Modality. $2^{\text {nd }}$ edn. Cambridge: Cambridge University Press.

PerlmutTer, DAVID. Impersonal passives and the Unaccusative Hypothesis. Berkeley Linguistic Society 4, 157-89.

Petré, Peter, and Hubert Cuyckens. 2009. Constructional change in Old and Middle English copular constructions and its impact on the lexicon. Folia Linguistica Historica 30: 31166.

PETRÉ, PETER. 2010. The functions of weorðan and its loss in the past tense in Old and Middle English. English Language and Linguistics, 14.457-84.

PETRÉ, PETER. 2014. Constructions and environments: Copular, passive, and related constructions in Old and Middle English. Oxford: Oxford University Press.

PUSTEJOVSY, JAMES. 1991. 'The syntax of event structure', Cognition 41: 47-81.

RANDALL, Beth. 2010. CorpusSearch. Version 2.002.74. Philadelphia: University of Pennsylvania, electronic.

ReICHENBACH, HANS. 1947. Elements of Symbolic Logic. New York: Free Press.

RINGE, DON, and ANN TAYLOR. 2014. The Development of Old English. (A Linguistic History of English, 2.) Oxford: Oxford University Press.

Rothmayr, ANTONia. 2009. The structure of stative verbs. Amsterdam: Benjamins.

RUPP, HEINZ. 1956. 'Zum “Passiv” im Althochdeutschen', Beiträge zur Geschichte der deutschen Sprache und Literatur 74, 265-86. Halle.

SCHRÖDER, WERNER. 1955: 'Zur Passiv-Bildung im Althochdeutschen', Beiträge zur Geschichte der deutschen Sprache und Literatur 77, 1-76. Halle. 
SCHRÖDER, WERNER. 1957. 'Die Gliederung des gotischen Passivs', Beiträge zur Geschichte der deutschen Sprache und Literatur 79, 1-105. Halle.

SCHRODT, RichARD. 2004. Althochdeutsche Grammatik II: Syntax. Tübingen: Niemeyer.

SweEt, Henry (ed.) 1871. King Alfred's West-Saxon Version of Gregory's Pastoral Care. (Early English Text Society, 45; 50.) London: Trübner.

Traugott, Elizabeth Closs, and Graeme Trousdale. 2013. Constructionalization and Constructional Changes. Oxford: Oxford University Press.

Valentin, Paul. 1987. 'Zur Geschichte des deutschen Passivs' in Das Passiv im Deutschen: Akten des Kolloquiums über das Passiv im Deutschen, Nizza, 1986. Tübingen: Niemeyer.

VENDLER, ZENO. 1967. Linguistics in Philosophy. Ithaca, NY: Cornell University Press.

VERKUYL, HENDRIK JACOB. 1972. On the Compositional Nature of the Aspects. Dordrecht: Reidel (Foundations of Language, 15).

VERKUYL, HENDRIK JACOB. 1993. A Theory of Aspectuality: The Interaction Between Temporal and Atemporal Structure. Cambridge: Cambridge University Press (Cambridge Studies in Linguistics, 64).

VISSER, F.T. 1973. An historical syntax of the English language, Vol III, part 2. Leiden: Brill.

Whitelock, Dorothy. 1962. 'The Old English Bede', Proceedings of the British Academy, 48.57-90.

YERKES, DAVID. 1982. Syntax and style in Old English: A comparison of the two versions of Worferth's translation of Gregory's Dialogues. Binghamton, NY: Center for Medieval \& Early Renaissance Studies.

YERKES, DAVID. 1986. The translation of Gregory's Dialogues and its revision: Textual history, provenance, authorship. Studies in Earlier Old English Prose, ed. by Paul E. Szarmach, 335-43. Albany: SUNY Press.

ZIEGLSCHMID, A. J. FRIEDRICH. 1929. Zur Entwicklung der Perfektumschreibung im Deutschen (Language Dissertations publ. by the Linguistic Society of America, 6) Baltimore: Waverley Press 